\title{
The mostly cavernicolous millipede genus Stygiiulus Verhoeff, 1929, stat. nov.: taxonomy, distribution and phylogenetic relationships (Diplopoda, Julida, Julidae)
}

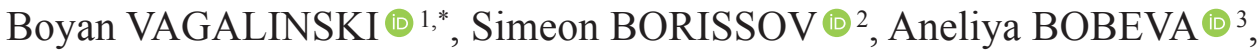 \\ Giacomo CANCIANI ${ }^{\circledR}{ }^{4} \&$ Dragan Ž. ANTIĆ ${ }^{\circ} 5$ \\ ${ }^{1,2,3}$ Institute of Biodiversity and Ecosystem Research, Bulgarian Academy of Sciences, \\ 2 Gagarin Street, 1113, Sofia, Bulgaria. \\ ${ }^{4}$ Jamarski Klub Kraški Krti/G.S. Talpe del Carso, loc. San Michele del Carso/Vrh, \\ I-34070 Savogna d'Isonzo (GO), Italy. \\ ${ }^{4}$ Associazione Speleologica Forum Julii Speleo, Via Carraria 99, I-33043 Cividale del Friuli (UD), Italy. \\ ${ }^{5}$ University of Belgrade - Faculty of Biology, Institute of Zoology, \\ Studentski Trg 16, 11000 Belgrade, Serbia. \\ ${ }^{5}$ Serbian Biospeleological Society, Trg Dositeja Obradovića 2, 21000 Novi Sad, Serbia. \\ *Corresponding author: boyanv84@gmail.com \\ 22Email: borissovsb@gmail.com \\ ${ }^{3}$ Email: aneliabobeva@gmail.com \\ ${ }^{4}$ Email: giacomo.canciani90@gmail.com \\ ${ }^{5}$ Email: dragan.antic@bio.bg.ac.rs

\footnotetext{
${ }^{1}$ urn:1sid:zoobank.org:author:CF6A5691-5C32-4CFF-9EB6-045DEB16F289

${ }^{2}$ urn:lsid:zoobank.org:author:C035E1AC-D4FB-4A3F-8B38-5D38A9665E88

${ }^{3}$ urn:lsid:zoobank.org:author:0F4EA315-46BE-49AC-8FB4-CF710C5B2451

${ }^{4}$ urn:lsid:zoobank.org:author:4BB21FD2-15C8-44BD-907A-4498D7D02A15

${ }^{5}$ urn:1sid:zoobank.org:author:2368C980-2042-4137-998D-8C91E4337185
}

\begin{abstract}
The blind and mostly endogean julid genus Stygiiulus Verhoeff, 1929 stat. nov. is reviewed to include ten species: S. ausugi (Manfredi, 1953) comb. nov., S. fimbriatus (Strasser, 1971) comb. et stat. nov., S. gentianae (Strasser, 1971) comb. et stat. nov., S. illyricus (Verhoeff, 1929) comb. nov., S. insularis (Strasser, 1938) comb. nov., S. maximus (Verhoeff, 1929) comb. nov., S. montellensis (Verhoeff, 1930) comb. nov., S. rotundatus (Strasser, 1962) comb. et stat. nov., S. seewaldi (Strasser, 1967) comb. nov., and S. tobias (Berlese, 1886) comb. nov. The distinctiveness of the genus from Typhloiulus is proven by both morphological and molecular data. The monotypic genus Alpityphlus Strasser, 1967 is here treated as a junior subjective synonym of Stygiiulus syn. nov. Stygiiulus fimbriatus comb. et stat. nov. and S. gentianae comb. et stat. nov., originally described as subspecies of $S$. ausugi comb. nov., are here erected to full species, while the subspecies $S$. illyricus stygis (Verhoeff, 1933) comb. et syn. nov. is considered to be a junior subjective synonym of the typical $S$. illyricus comb. nov. Lectotypes are formally designated for $S$. gentianae comb. et stat. nov. and S. rotundatus comb. et stat. nov., to stabilize the nomenclature of the two species under Article 74.1 of the ICZN. The phylogeny of the genus, its distribution patterns, and the modified mouthparts in some of its species are discussed.
\end{abstract}


Keywords. Typhloiulus, new combination, new synonymy, lectotype designation, modified mouthparts.

Vagalinski B., Borissov S., Bobeva A., Canciani G. \& Antić D.Ž. 2022. The mostly cavernicolous millipede genus Stygiiulus Verhoeff, 1929, stat. nov.: taxonomy, distribution and phylogenetic relationships (Diplopoda, Julida, Julidae). European Journal of Taxonomy 798: 30-69.

https://doi.org/10.5852/ejt.2022.798.1669

\section{Introduction}

Millipedes live primarily in the leaf litter and the superficial soil layer, with the great majority of them being confined to forested areas of various types. However, the deep subterranean domain (including caves) is another habitat that gives shelter to numerous diplopods, some of which are adapted to living under its specific conditions. Most of the larger millipede orders contain considerable number of species, genera, and even whole families that are, or mostly contain, troglobionts (Golovatch 2009; Liu et al. 2017).

In the predominantly Palaearctic order Julida, proportionally the most troglobionts are found in the families Blaniulidae and Trichoblaniulidae (Kime \& Enghoff 2017). However, the most speciose family by far, Julidae, is relatively scarce in obligate cavernicoles, with most tribes and genera including only a small number of such species. The large genus Typhloiulus Latzel, 1884 (see Latzel 1884) is a notable exception, as it comprises only a few species known from superficial or shallow subterranean habitats, while the rest are recorded exclusively from caves. This along with the still insufficiently studied taxonomy and the highly unresolved phylogeny of the genus have lead to an increased interest in it in recent years (Vagalinski et al. 2015; Makarov et al. 2017; Antić et al. 2017, 2018). Some of these studies indicated that Typhloiulus is likely non-monophyletic. This is also reflected by the current taxonomy of the genus which includes several distinct subgenera, some of which probably deserve the status of separate genera. Here we revise one of these subgenera - the circum-Alpine Stygiiulus Verhoeff, 1929.

Until now, the subgenus Stygiiulus was considered to comprise four unquestionable species: Typhloiulus illyricus Verhoeff, 1929 (the type species, see Verhoeff 1929), T. ausugi Manfredi, 1953, T. montellensis Verhoeff, 1930, and T. maximus (Verhoeff, 1929) (see Strasser 1962). Vagalinski et al. (2015) suggested that T. tobias (Berlese, 1886), albeit somewhat deviating from the above-listed species, might be another member of Stygiiulus, and Antic et al. (2017, 2018) made the same assumption regarding T. seewaldi (Strasser, 1967) originally described in a separate genus, Alpityphlus Strasser, 1967 (see Strasser 1967), and T. insularis Strasser, 1938. In the present paper we confirm the taxonomy of the three latter species under Stygiiulus stat. nov. and add three more that have hitherto been treated as subspecies of T. ausugi and T. montellensis. In addition, we elevate Stygiiulus stat. nov. to full generic rank based on both morphological and genetic data.

\section{Material and methods}

\section{Material preservation and deposition}

Most specimens are preserved in 70\% ethanol, except for one sample of Stygiiulus fimbriatus comb. et stat. nov., collected in 2019 in 95\% ethanol and used subsequently for genetic analyses.

The material used for the present study is deposited in CBSS (Croatian Biospeleological Society, Zagreb, Croatia), IBER (Institute of Biodiversity and Ecosystem Research at the Bulgarian Academy of Sciences, Sofia, Bulgaria), IZB (Institute of Zoology, University of Belgrade - Faculty of Biology, Belgrade, Serbia), NMNHS (National Museum of Natural History, Sofia, Bulgaria), MHNG (Muséum d'histoire naturelle, Geneva, Switzerland), and NHMD (Natural History Museum of Denmark, Copenhagen, Denmark (formerly ZMUC - Zoological Museum, University of Copenhagen). 


\section{Morphological study and imaging}

Specimens were examined with a Nikon SMZ 745T and an МБC 10 binocular stereo microscopes (IZB and IBER, respectively). Permanent microscopic slides (MHNG) and temporary glycerine microscope preparations with taxonomically important structures dissected and mounted in the course of the present study were observed with a Carl Zeiss Axioscope 40 microscope (IZB) and a Zeiss Axio Imager 2 microscope (IBER). Drawings of gonopods, penes, male leg-pair 1, and vulvae were obtained using tracing paper placed on a computer monitor displaying pictures of those structures made with a Canon PowerShot A80 digital camera connected to the Carl Zeiss Axioscope 40 microscope and stacked with Zerene Stacker (IZB) or with a ProgRes C7 digital camera connected to a Zeiss Axio Imager 2 microscope and stacked with Helicon Focus 6 (IBER). Pictures of the specimens and relevant habitus structures were taken using a Nikon DS-Fi2 camera with a Nikon DS-L3 camera controller attached to a Nikon SMZ 1270 binocular stereo microscope (IZB). Measurements were performed using a Carl Zeiss Stemi 2000-c binocular stereomicroscope with an AxioCam MRc camera (IZB) and an ocular grid mounted on one of the eyepieces of the МБC 10 binocular stereo microscope (IBER). For Scanning electron microscopy (SEM) the examined morphological structures were air-dried, mounted on glass or metal pads, and sputter-coated with gold for imaging in JEOL JSM-5510 (Chemical Faculty, Sofia University, Sofia, Bulgaria) or with carbon for imaging in JEOL JSM-6010 PLUS/LA (University of Mining and Geology "St. Ivan Rilski”, Sofia, Bulgaria).

The distribution maps were created using Google Earth Pro (vers. 7.3.4.8248) and Adobe Photoshop CS6. The final images were processed with Adobe Photoshop CS6.

\section{Descriptive abbreviations}

$\mathrm{BRF}=$ body ring formula

$\mathrm{H}=$ vertical diameter at mid-body

$\mathrm{L}=$ body length measured at ozopore level

Abbreviations referring to gonopodal, vulval and oral structures are explained both in the text and in the figure captions.

\section{Molecular analyses}

Total DNA from Stygiiulus fimbriatus comb. et stat. nov. was extracted via DNeasy Blood \& Tissue Kit (Qiagen, Inc.) according to manufacturers' instructions. The obtained product was quantified by NanoDrop2000 (Thermo Scientific) and diluted to a standard concentration of $25-50 \mathrm{ng} / \mu \mathrm{l}$. In order to amplify fragments of the nuclear $28 \mathrm{~S}$ rDNA and the mitochondrial $16 \mathrm{~S}$ rDNA, polymerase chain reaction was performed using HotStarTaq Plus Master Mix (Qiagen, Inc.). The primers used for 28S rDNA were 28S rDNA-FW 5'-CCCGTCTTGAAACACGGACCAA-3' and 28S rDNA-RE 5'-CCACAGCGCCAGTTCTGCTTAC-3'. The reaction was performed at $94^{\circ} \mathrm{C}$ for $5 \mathrm{~min}$ followed by 35 cycles of denaturation at $94^{\circ} \mathrm{C}$ for $1 \mathrm{~min}$, annealing at $55^{\circ} \mathrm{C}$ for $30 \mathrm{sec}$, and extension at $72^{\circ} \mathrm{C}$ for 1 min (Muraji \& Tachikawa 2000). The final cycle was completed with $10 \mathrm{~min}$ of extension at $72^{\circ} \mathrm{C}$. For 16S rDNA we used LR-J-12961 5'-TTTAATCCAACATCGAGG-3' (Cognato \& Vogler 2001) and LR-N-13398 5'-CGCCTGTTTAACAAAAACAT-3' (Simon et al. 1994). The reaction was performed at $94^{\circ} \mathrm{C}$ for $5 \mathrm{~min}$ followed by 5 cycles of denaturation at $94^{\circ} \mathrm{C}$ for $1.5 \mathrm{~min}$, annealing at $44^{\circ} \mathrm{C}$ for $1 \mathrm{~min}$ and extension at $72^{\circ} \mathrm{C}$ for $1.5 \mathrm{~min}$, and 30 cycles at $94^{\circ} \mathrm{C}$ for $1.5 \mathrm{~min}, 48^{\circ} \mathrm{C}$ for $1 \mathrm{~min}$ and $72^{\circ} \mathrm{C}$ for $1.5 \mathrm{~min}$ (Kutty et al. 2007). The final cycle was completed with $10 \mathrm{~min}$ of extension at $72^{\circ} \mathrm{C}$. The presence of amplicons with an appropriate length was visualized on $2 \%$ agarose gel stained with GelRed (Biotium, Inc.) using $3 \mu 1$ of the reaction. Amplified fragments were then sequenced at Macrogen Europe B.V. (Amsterdam, the Netherlands). 


\section{Genetic data analyses}

Trimming, assembly and visual preparation of the newly obtained sequences were performed in CodonCode Aligner version 8.0.2 (CodonCode, Dedham, MA, USA). DNA sequences from the mitochondrial 16S rRNA and the nuclear 28S rRNA of closely related taxa and outgroups were downloaded from GenBank (Supplementary file 1). Sequence alignments were performed in MEGA X (Kumar et al. 2018) in two separate datasets. Unique sequences were selected with DAMBE 7.0.39 (Xia 2018). Best substitution models for matrices were selected using PartitionFinder ver. 2.1.1 (Lanfear et al. 2017) on the CIPRES Science Gateway server (Miller et al. 2011). Phylogenetic analyses were run on the two datasets (16S rRNA and 28S rRNA) and on a concatenated 16S rRNA+28S rRNA matrix. Maximum likelihood (ML) analyses were performed with RAxML ver. 8.2.12 (Stamatakis 2014) on the CIPRES Science Gateway using 1000 bootstrap resampling to obtain node support. Bayesian inference analyses (BI) were carried out with Mr Bayes 3.2.5 (Ronquist et al. 2012) with four simulations of Markov chains and $4 \times 10^{6}$ generations, sampling one of every 100 trees. The MCMC parameters were monitored in Tracer ver. 1.7.1 (Rambaut et al. 2018). The first $25 \%$ of trees were removed as burnin.

\section{Results}

\section{Taxonomy}

Class Diplopoda de Blainville in Gervais, 1844

Order Julida Brandt, 1833

Family Julidae Leach, 1814

Genus Stygiiulus Verhoeff, 1929 stat. nov.

Stygiiulus Verhoeff, 1929: 20 (as subgenus of Typhloiulus Latzel, 1884).

Alpityphlus Strasser, 1967: 146, syn. nov.

\section{Type species}

Typhloiulus (Stygiiulus) illyricus Verhoeff, 1929 (by monotypy)

\section{Diagnosis}

A genus of blind Julidae characterized by a flagellum-bearing promere, a true mesomere, and an opisthomere with a well-developed velum. Differing from other blind leptoiulinine/typhloiulinine genera by the following combination of characters: promere with an internal and an external lobe on caudal face, both without setae; opisthomere rather slender, devoid of any distinct processes on caudal and lateral side, and possessing a lamellar, marginally often (but not always) serrated or ciliate velum and an apically bifid solenomere (one or both solenomeral branches vestigial in some species), with the exception of (some variations of) $S$. tobias (Berlese, 1886) comb. nov. in which the solenomere apically possesses a minute third branch behind the main two; and hypoproct either blunt or rounded, tightly fitting under paraprocts in both sexes.

\section{Characterization}

- Small (L from $10 \mathrm{~mm}$ ) to large (L up to $70 \mathrm{~mm}$ ) Julidae.

- Colouration pallid to light brown-grey.

- Ommatidia absent.

- Ozopores set considerably (rarely closely) behind pro-metazonal suture.

- Epiproct present, varying from short to very long, mostly straight.

- Hypoproct rounded or subtriangular, not or only insignificantly protruding behind rear contour of paraprocts, ventrally setose.

- Male mandibular stipites not expanded. 
- Male walking legs ventrally with a well-developed adhesive pad on tibia at least in more frontal leg-pairs, some species also with a less pronounced pad on postfemur.

- Male pleurotergum 7 with expanded ventral margin forming a rather weakly pronounced lobe in its caudal section.

- Penis (not observed in S. seewaldi comb. nov.) long and slender, with short and stout apical lobes and fine, narrow terminal lamellae.

\section{Gonopods}

- Slender, solenomere more or less exceeding both pro- and mesomere in height.

- Promere roughly oar-shaped, with more or less well-developed internal and external lobe, these not bearing setae.

- Mesomere usually subequal to (rarely significantly shorter than) promere.

- Opisthomere simple, rather elongate, lacking paracoxal or other processes in its proximal or middle part, some species with a characteristic posterior hump at mid-distal level; subapically on frontal side with well-developed lamellar velum with often serrated or fringed margin; solenomere apically divided in two (rarely three) small branches - an anterior and a posterior one - with their tips often bearing several minute thread-like filaments; some species with one or both branches very weakly pronounced, difficult to detect.

- Basal spine at flagellum channel, with some exceptions (see below), usually absent.

\section{Vulva (not observed in $S$. seewaldi comb. nov.)}

- Operculum higher than bursa.

- Median cleft of bursa shallow.

- Receptaculum seminis consisting of two narrow and short (in relation to size of vulva) tubes (except for $S$. tobias comb. nov. in which both tubes are rather long), sometimes forming distinct ampullas at bottom.

Stygiiulus ausugi (Manfredi, 1953) comb. nov.

Figs 10A, 11A, 13

Typhloiulus ausugi Manfredi, 1953b: 136-138, figs 1-2.

Typhloiulus (Stygiiulus) ausugi - Strasser 1962: 11, 12, 18, 37, 38, figs 1-2, 8, 11h, 15, 41-44.

Typhloiulus (Stygiiulus) ausugi ausugi - Strasser 1971a: 13.

Typhloiulus ausugi ausugi - Minelli 1985: 9.

Typhloiulus ausugi - Vagalinski et al. 2015: 336-337.

\section{Diagnosis}

One of the three species of Stygiiulus stat. nov. with modified mouthparts, the other two being $S$. fimbriatus comb. et stat. nov. and $S$. gentianae comb. et stat. nov. Differs from both mainly by the complete absence of posterior hump on opisthomere, the very large velum with minute fringes on posterodistal margin, and the anterior and posterior solenomeral branches both being very short, hardly distinguishable.

\section{Material examined}

ITALY - Trentino (Autonomous Province of Trento) - 1 \%; topotype; Altopiano dei Sette Comuni, Grigno, Grotta [Cave] della Bigonda (243 VT/TN); 450 m a.s.l.; 10 Mar. 1996; G. Peretto and E. Piva leg.; H. Enghoff det. 2013; NHMD • 1 \%; Grigno, Grotta [Cave] del Calgeron (new record), a side branch of the waterfall; Dec. 1973; Ischia leg.; H. Enghoff det. 1984; A. Minelli ded. 1985; NHMD. 


\section{Descriptive notes}

Antennae. 2-2.1 times as long as head and 1.7-1.75 times as long as $\mathrm{H}$ in males, and 1.7-1.8 times and ca 1.4 times, respectively, in females; antennomere 5 ca twice as long as broad; antennomeres 2 , 3 and 4 subequal in length, ca 1.2 times as long as 5, and 1.7-1.8 times as long as $6 ; 6$ visibly broader than 5 , giving a clavate appearance of the antenna.

MouthParts. With strong hydrophilous modifications (sensu Enghoff 1985): labrum edentate or with three minute, vestigial teeth. Gnathochilarium short and distally markedly broad, stipites with conspicuously large palps. Gnathal lobes of mandibles with the external and the internal tooth strongly reduced, both being distinct but very small and pointed, deeply hidden in the buccal cavity; molar plate much smaller than the normal julid condition; pectinate lamellae five instead of the usual four, consisting of very fine and densely set teeth.

TARSUS OF MID-BOdy Legs. Ca 2.5 times as long as tibia and ca 5 times as long as apical claw. Mid-body legs ca 1.7 times as long as $\mathrm{H}$ in males and ca 1.4 times in females.

Female SeXual Characters. Legs 1 and 2 slightly shorter but not thicker than following legs. Vulva (Fig. 11A) symmetric; bursa very broad, strongly compressed in the sagittal plane; each valve of bursa with one vertical row of setae; operculum (op) distally bulging, with a distinct apical concavity, exceeding bursa by nearly $1 / 3$ of total height of vulva, with just several setae each side. Receptaculum seminis consisting of two small tubes: a very fine, somewhat bent, mesal one (mt) ending in a small ovoid ampulla (ma), and a significantly broader, mostly straight, lateral one (lt), not forming ampulla at bottom.

\section{Distribution}

Prior to this study, the species was known only from its type locality - the Grotta della Bigonda - on the northern border of the central part of the Venetian Prealps. The new locality of this species - the Grotta del Calgeron - is located in the same area, some $20 \mathrm{~km}$ south of the type locality (Fig. 13, blue circles).

\section{Remarks}

Strasser (1971a) described two subspecies of ausugi, viz., fimbriatus and gentianae. Considering the gonopod conformations of the two latter forms, both of which differ significantly from $S$. ausugi comb. nov. and are instead much more similar to $S$. illyricus comb. nov., S. maximus comb. nov., $S$. montellensis comb. nov., and $S$. rotundatus comb. et stat. nov., it becomes obvious that Strasser (1971a) treated the modified mouthparts as a taxonomic feature of primary importance, being unaware of the adaptive nature of such modifications, as revealed later by Enghoff (1985). Thus we here elevate fimbriatus and gentianae to the species level and describe both of them in detail below.

In the Grotta della Bigonda, this species lives in sympatry with $S$. tobias comb. nov.

Stygiiulus fimbriatus (Strasser, 1971) comb. et stat. nov.

Figs $1-3,13$

Typhloiulus ausugi fimbriatus Strasser, 1971a: 13-14, fig. 14.

Typhloiulus ausugi fimbriatus - Minelli 1985: 10. — Vagalinski et al. 2015: 336-337.

\section{Diagnosis}

A species of Stygiiulus stat. nov. with modified mouthparts. Differs from its most similar congener, S. gentianae comb. et stat. nov., by gonopod details, viz. both promere and mesomere being apically bent 

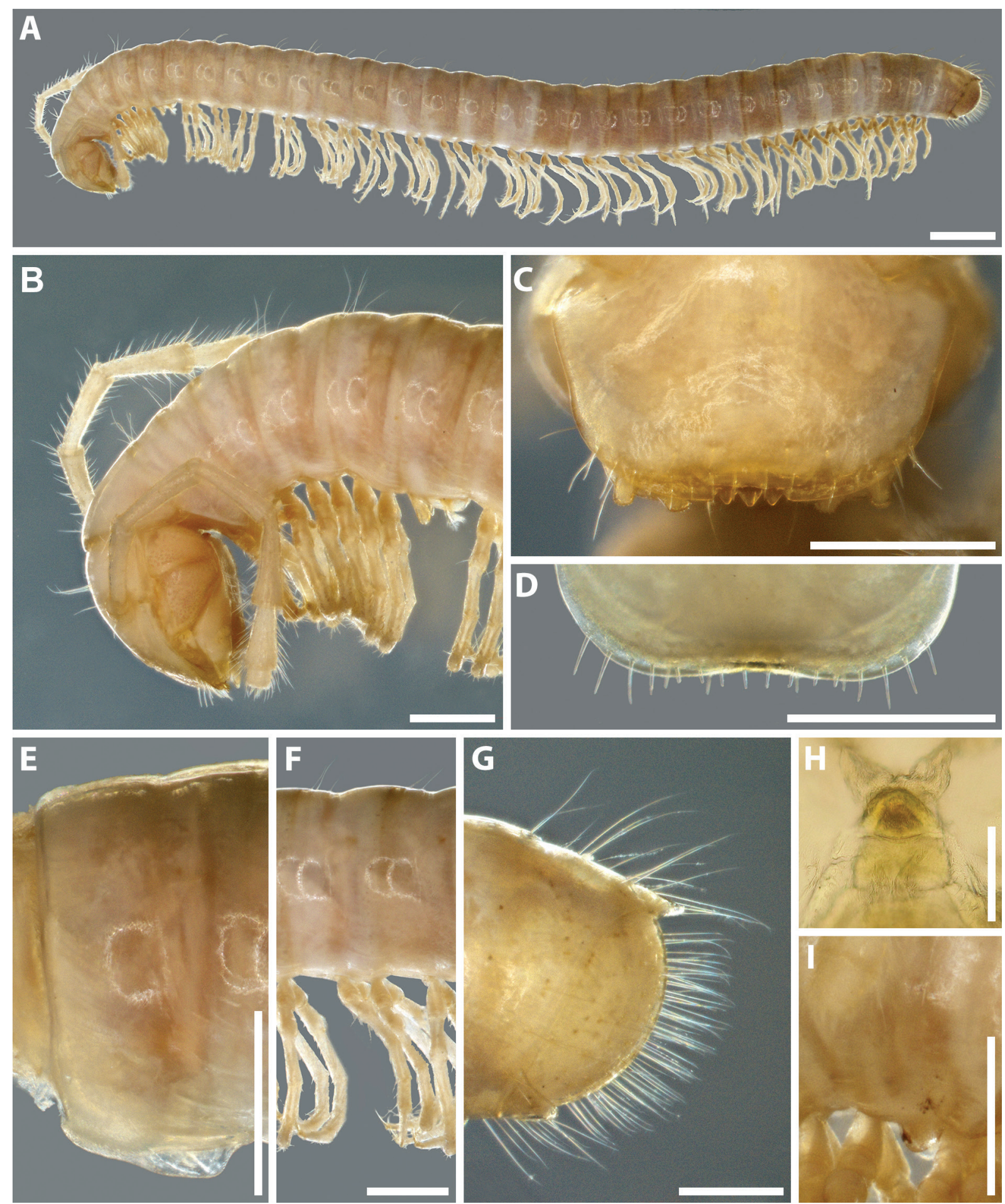

Fig. 1. Stygiiulus fimbriatus (Strasser, 1971) comb. et stat. nov., $ð \widehat{\jmath}(\mathrm{A}-\mathrm{H})$ and $q$ (I) from Foran di Landri Cave (IZB). A. Habitus, lateral view. B. Anterior part of body, lateral view. C. Labrum, frontodorsal view. D. Labrum, dorsal view. E. Pleurotergum 7, lateral view. F. Mid-body rings, lateral view. G. Telson, lateral view. H. Posterior node of hypopharynx, fronto-ventral view. I. Lobe of body ring 3, lateral view. Scale bars: $A=1 \mathrm{~mm} ; B-G, I=0.5 \mathrm{~mm} ; \mathrm{H}=0.1 \mathrm{~mm}$. 
frontad rather than turned towards one another, velum being marginally serrated all along rather than having a smooth anterior margin; by the more pronounced posterior part of pleurotergal flange 7 in males; by the vulval operculum being concave rather than convex, exceeding bursa by ca $1 / 4$ rather than $2 / 5$ of total height of vulva; by the presence of a small, roundish anterior lobe on ventral margin of body ring 3 in females, vs ventral margin of body ring 3 in females being almost entirely subtriangular in $S$. gentianae comb. et stat. nov., and by the somewhat longer epiproct.

\section{Material examined}

\section{Holotype}

ITALY - ${ }^{7}$; slide preparation plus ethanol sample; Friuli-Venezia Giulia, San Pietro al Natisone, Grotta [cave] di San Giovanni d'Antro; slide no. 1003: gonopods, antennae, leg-pairs 1, 2, 3, 7, penis, gnathochilarium, flanges of pleurotergum 7; ethanol sample: broken in six pieces; MHNG-ARTO-26720.

\section{Other material}

ITALY • $3 \widehat{\jmath}$, 1 क; Friuli-Venezia Giulia, Prestento di Torreano, Foran di Landri Cave (11 / 46FR);

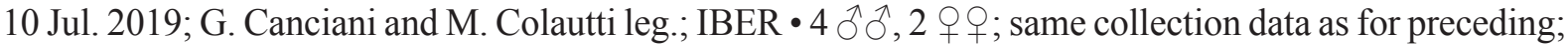
IZB $\bullet 1$; ; same collection data as for preceding; NHMD.

\section{Comment}

Since the original description was based upon one male which was not designated by Strasser (1971a) as holotype, we here consider that male as a holotype fixed by monotypy, in order to stabilize the nomenclature of the species under Article 73.1.2 of the ICZN.

\section{Redescription}

Size AND NUMBER OF BODY RINGS. Non-type $\widehat{\jmath}$ त with BRF $26-31+0-1+\mathrm{T}, \mathrm{L}=14-20 \mathrm{~mm}, \mathrm{H}=1.1-$ $1.25 \mathrm{~mm}$; non-type 우 with BRF 28-32+0-1+ T, $\mathrm{L}=16-21 \mathrm{~mm}, \mathrm{H}=1.3-1.6 \mathrm{~mm}$.

Colouration (Fig. 1A-B, E-G). Generally brown-beige; metazonae with a narrow transverse dark brown band before their last third, the band gradually narrowing ventrally.

EXTERNAL STRUCTURES. Head with 2 vertigial, $2+2$ supralabral and 16-18 labral setae. Antennae (Fig. 1B) 2.3 times as long as head and 2.3-2.4 times as long as $\mathrm{H}$ in males, and 2 times and 1.85-1.9 times, respectively, in females; antennomere $53.12-3.15$ times as long as broad; antennomeres 2-5 subequal in length, 1.3-1.6 times as long as 6. Antennomeres V and VI each with a terminal corolla of large sensilla basiconica bacilliformia; antennomere VII with a terminal corolla of small sensilla basiconica bacilliformia.

MouthPARTs (Figs 1C-D, H, 2A-B). With moderate hydrophilous modifications (sensu Enghoff 1985): Labrum either edentate (Fig. 1D) or with three well-developed labral teeth (Fig. 1C). Gnathochilarium (Fig. 2A) rather short and distally markedly broad, with the 3 long distal setae on each stipes usual for the family, stipites medially each with 4-10 short setae arranged longitudinally, stipital palps conspicuously large; promentum large (pm), completely separating lingual lamellae, the latter each with 2-3 proximal and 1 distal seta. Gnathal lobes of mandibles (Fig. 2B) with the external (et) and the internal tooth (it) slightly to moderately reduced; molar plate (mp) relatively small (but larger compared to that in $S$. ausugi comb. nov.); the four pectinate lamellae ( $\mathrm{pl}$ ) consisting of slender and very densely set teeth. Hypopharynx distally densely ciliate, posterior node reduced, with roundish posterior margin (Fig. 1H).

Collum. Entirely smooth, its frontolateral margin bent outwards. Body rings considerably vaulted. Prozonae smooth. Metazonae with well-developed striation only ventrally, dorsally and laterally with faint and short striae only in anterior parts; setae ca $20 \%$ of $\mathrm{H}$ (Fig. 1F), arranged in moderately dense 

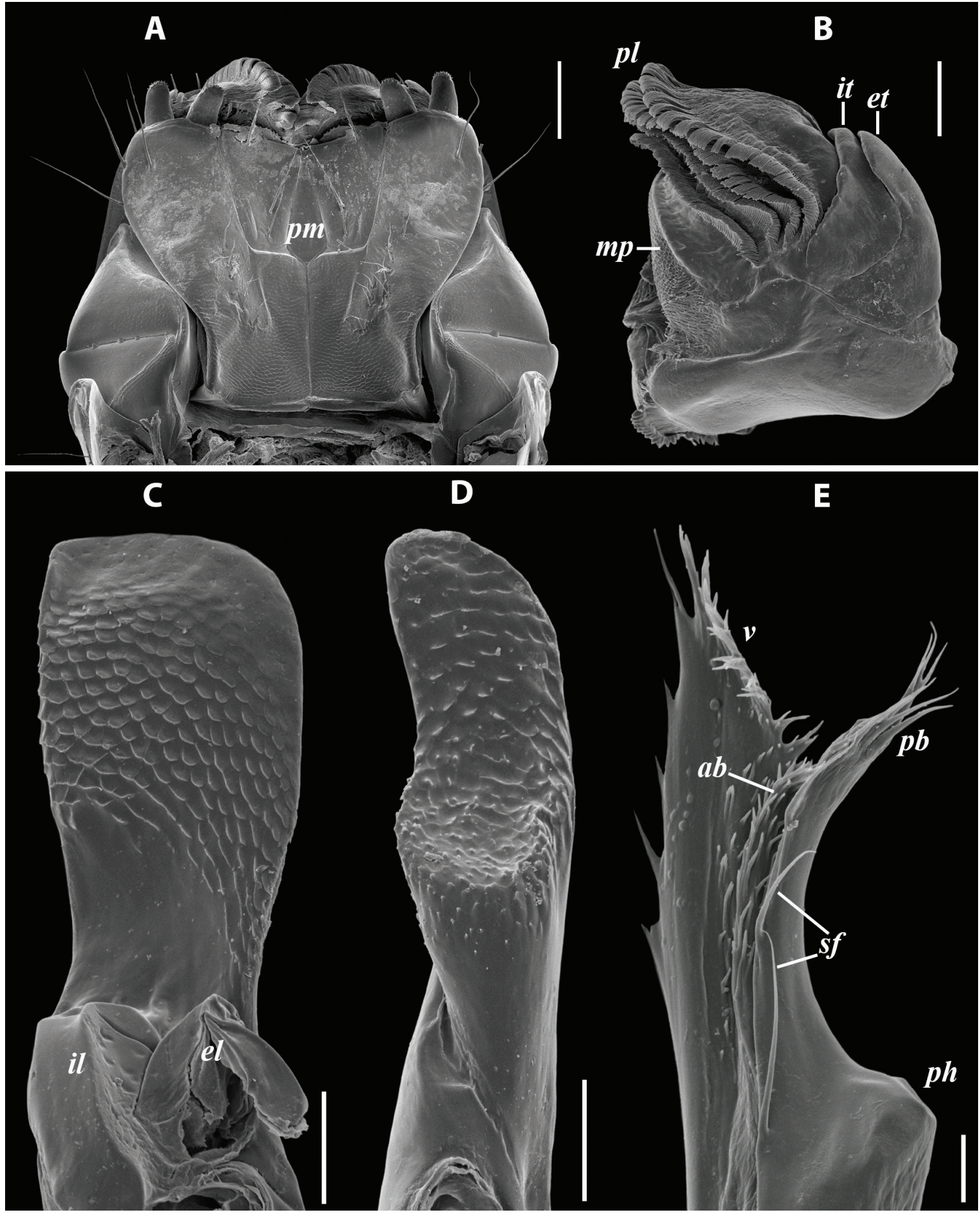

Fig. 2. Stygiiulus fimbriatus (Strasser, 1971) comb. et stat. nov., đ from from Foran di Landri Cave (IBER). A. Gnathochilarium, ventral view. B. Gnathal lobe of left mandible, ventral view. C. Left promere, caudal view. D. Left mesomere, oral view. E. Distal part of left opisthomere, mesal view. Abbreviations: $\mathrm{ab}=$ anterior branch of solenomere; el = external lobe; et $=$ external tooth; $\mathrm{il}=$ internal lobe; it = internal tooth; $\mathrm{mp}=$ mollar plate; $\mathrm{pb}=$ posterior branch of solenomere; $\mathrm{ph}=$ posterior hump; $\mathrm{pl}=$ pectinate lamellae; $\mathrm{pm}=$ promentum; $\mathrm{sf}=$ setiform filaments; $\mathrm{v}=$ velum. Scale bars: $\mathrm{A}=0.2 \mathrm{~mm}$; $\mathrm{B}=0.1 \mathrm{~mm} ; \mathrm{C}-\mathrm{D}=0.05 \mathrm{~mm} ; \mathrm{E}=0.02 \mathrm{~mm}$. 
whorl. Ozopores very small, placed behind pro-metazonal suture at ca $2 / 5$ of metazonal length measured from front to back. Tarsus of mid-body legs 2.2-2.4 times as long as tibia and 2.8-3.7 times as long as apical claw; accessory claw absent. Mid-body legs 1.5-1.6 times as long as $\mathrm{H}$ in males, 1.4 times in females.

TELSON (Fig. 1G). Epiproct short and stout, straight all along, ending with a short hyaline tip turned more or less dorsad, barely protruding behind caudal contour of paraprocts. Hypoproct broadly rounded, tightly fitting under paraprocts, with rather evenly setose ventral face. Paraprocts densely covered with long setae, without distinct rows of shorter setae along caudal margins.

Male SeXual Characters. Leg-pair 1 (Fig. 3A) rather slender hooks oriented towards one another; with three complete and another one or two faintly indicated segments; with apically densely microdentate tibial outgrowths, and without or with barely visible tarsal remnants. Legs of more anterior body rings with an adhesive pad on tibia, most pronounced in leg-pair 2, gradually diminishing in caudal direction, completely disappearing around mid-body; tibia and femora without modifications. Pleurotergum 7 (Fig. 1E) caudo-ventrally forming small rounded lobes directed caudad. Penis (Fig. 3B) long, in situ visible behind coxae 2, slender hourglass shaped: broadest at base, narrowing until the middle, then slightly widening again, ending with short, diverging, apical lobes bearing fine, blunt, terminal lamellae.

Gonopods (Figs 1B, 2C-E, 3C). In situ obliquely protruding from gonopodal sinus with their distal parts (Fig. 1B). Promere (Fig. 2C, p in Fig. 3C) somewhat higher than mesomere, both being significantly surpassed by the opisthomere. Promere stout, oar-shaped (broadest apically), forming a near rightangled meso-apical corner and a broadly rounded latero-apical corner; apical margin bent somewhat frontad; caudal face distally densely microsquamose, basally with an internal and an external lobe, both being short and robust, partly fused to one another. Mesomere (Fig. 2D, m in Fig. 3C) narrow spoon-like, with the apex turned meso-frontad; caudal face distally deeply concave and sparsely microsquamose. Opisthomere (Figs 2E, 3C) markedly slender, with a distinct, obtuse posterior hump (ph); velum (v) pointing distad, both its frontal and caudal margin apically deeply serrated; solenomere with a slender posterior branch $(\mathrm{pb})$ bent caudad, ending with several long ciliae, anterior branch ( $\mathrm{ab}$ ) vestigial, barely protruding, mostly concealed between the velum and the posterior solenomeral branch, densely ciliate; with 2 or 3 fine distal setiform filaments (sf), and sometimes with a variously developed basal spine (bs) at flagellum channel (fc).

Female SEXUAL CHARACTERs. Leg-pairs 1 and 2 visibly shorter, 1 also thicker, than following legs. Ventral margin of body ring 3 with roundish anterior lobe (Fig. 1I). Vulva (Fig. 3D) somewhat compressed in the sagittal plane, mostly symmetric: lateral side of operculum higher and apically more pointed than mesal one; each valve of bursa with one vertical row of setae; operculum (op) broad and thick, with a concave apical margin, exceeding bursa by ca $1 / 4$ of total height of vulva, medio-laterally with two longitudinal rows of setae each side. Receptaculum seminis consisting of two short and narrow, somewhat folded tubes - a lateral (1t) and a mesal one ( $\mathrm{mt}$ ), both insignificantly widening towards bottom, not forming distinct ampullae.

\section{Distribution}

Known only from two caves in the Julian Alps in Italy, near the border with Slovenia (Fig. 13, yellow circles).

\section{Remark}

The new locality of S. fimbriatus comb. et stat. nov., Cave Foran di Landri, is an active cave with a stream running through it year-round, flowing out of the entrance, after passing through a series of syphons 

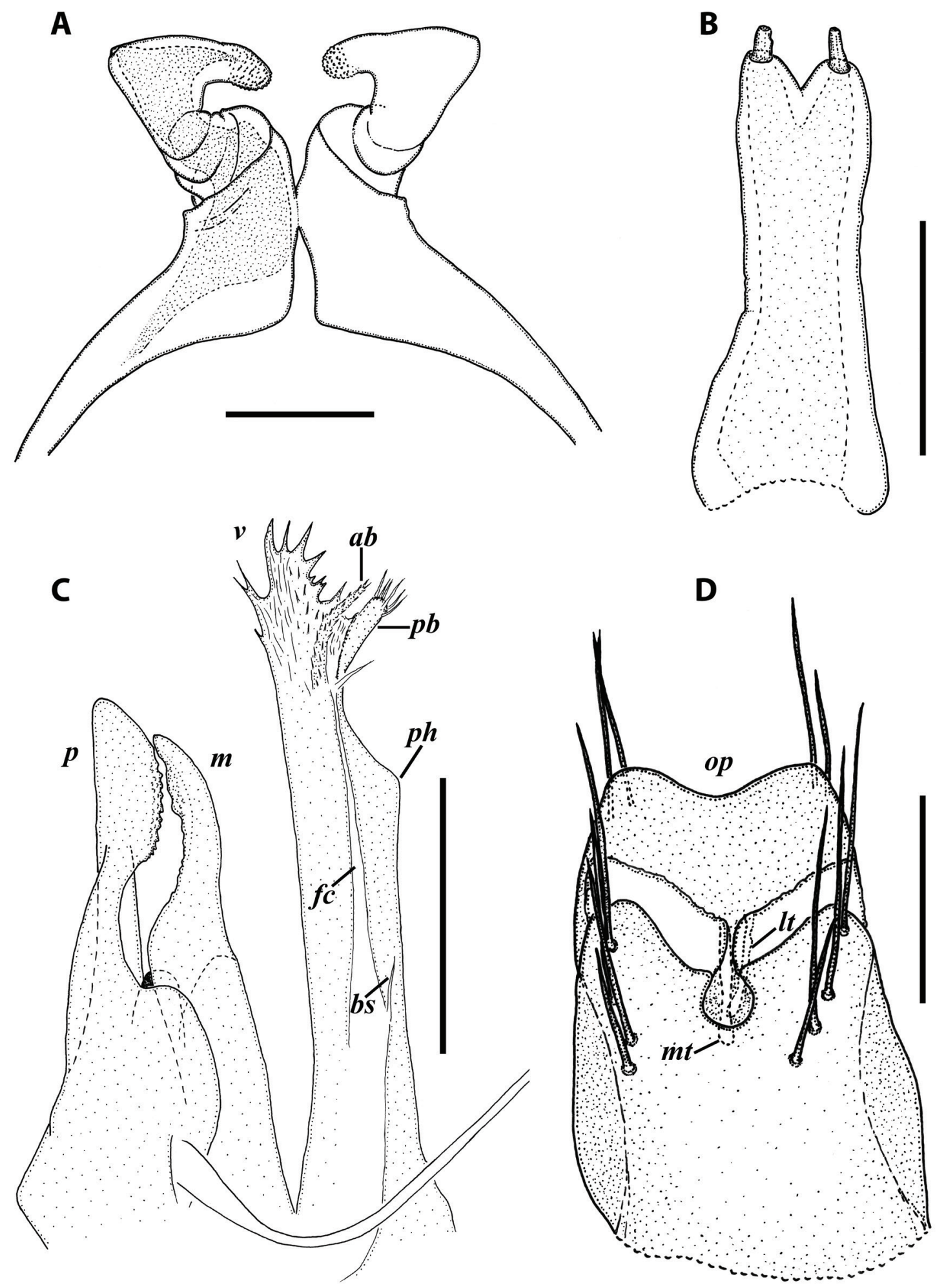

Fig. 3. Stygiiulus fimbriatus (Strasser, 1971) comb. et stat. nov., holotype $\widehat{\partial}$ (A, B) (MHNG), $\widehat{\partial}$ (C) (IZB) and $q$ (D) (IBER) from Foran di Landri Cave. A. Leg-pair 1, caudal view. B. Penis, oral/caudal view. C. Left gonopods, mesal view. D. Left vulva, caudal, somewhat mesal view. Abbreviations: ab = anterior branch of solenomere; $\mathrm{bs}=$ basal spine; $\mathrm{fc}=$ flagellum channel; $1 \mathrm{t}=$ lateral tube; $\mathrm{m}=$ mesomere; $\mathrm{mt}=$ median tube; $\mathrm{op}=$ operculum; $\mathrm{p}=$ promere; $\mathrm{pb}=$ posterior branch of solenomere; $\mathrm{ph}=$ posterior hump; $\mathrm{v}=$ velum. Scale bars $=0.2 \mathrm{~mm}$. 
(four discovered so far). All examined specimens were found right beyond the first two syphons, ca 40 meters from the entrance. This part of the cave includes a number of ponds, and it probably becomes completely flooded during rainy periods (Canciani 2019). Part of the individuals was observed moving on the surface of the ponds - a behaviour most likely associated with a filtrating rather than chewing feeding mode, in which small organic particles adhere to the fine and densely set teeth of the pectinate lamellae and to the cilia of the hypopharynx.

The cave of San Giovanni d'Antro (the type locality) is of the same type as Foran di Landri, and Strasser (1971a) noted that it was occasionally flooded.

Stygiiulus gentianae (Strasser, 1971) comb. et stat. nov.

Figs 4-6, 13

Typhloiulus ausugi gentianae Strasser, 1971a: 13-14, fig. 15.

Typhloiulus ausugi gentianae - Minelli 1985: 10. — Vagalinski et al. 2015: 336-337.

\section{Material examined}

Lectotype (designated here)

ITALY - O; Veneto, Bosco del Cansiglio [Cansiglio Forest], Bus [cave] de la Genziana; specimen unbroken; MHNG-ARTO-26721.

\section{Paralectotypes}

ITALY • 1 q; same collection data as for lectotype; specimen unbroken; MHNG-ARTO-26722 • $1 \hat{\delta}$ slide preparation; same collection data as for lectotype; labrum, mandibles, gnathochilarium, antennae, penis, flanges of pleurotergum 7; MHNG-ARTO-26723 • 1 त slide preparation; same collection data as for lectotype; gonopods; MHNG-ARTO-26724.

\section{Other material}

ITALY 1 topotype 9 ; Veneto, province of Treviso, Bosco del Cansiglio [Cansiglio Forest], Fregona, q. 1020, Bus [cave] de la Genziana (1000 V/TV); 3 Oct. 1985; E. Piva leg. and ded.; NHMD • 1 topotype $\widehat{\text { O, }}$ 2 topotype 9 ㅇ; same locality as for preceding; 22. Oct. 1994; E. Piva leg.; H. Enghoff det. 2013; NHMD •

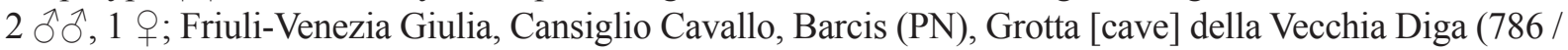

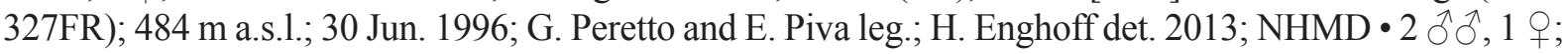
Friuli-Venezia Giulia, province of Pordenone, Montereale Valcellina (PN), Inghiottitoio [karstic pot-hole] della Val di Pai (1027 / 469FR); 30 Aug. 1984; Comotti leg.; R. Pisoni ded. 1989; NHMD.

\section{Comment}

Since the original description was based upon three males and two females, none of which was designated by Strasser (1971a) as holotype, we here designate the only intact male specimen as lectotype, in order to stabilize the nomenclature of the species under Article 74.1 of the ICZN.

\section{Diagnosis}

A species of Stygiiulus stat. nov. with modified mouthparts. Differs from its most similar congener, S. fimbriatus comb. et stat. nov., by gonopod details, viz. promere and opisthomere being turned towards one another rather than apically both bent frontad, velum with a smooth rather than entirely serrated anterior margin; by the weakly rather than strongly pronounced posterior part of pleurotergal flange 7 in males; by the vulval operculum being convex rather than concave, exceeding bursa by ca $2 / 5$ rather than with $1 / 4$ of total height of vulva; by the entirely subtriangular ventral margin of body ring 3 in females, rather than ventral margin with a small, roundish anterior lobe; and by the somewhat shorter epiproct. 

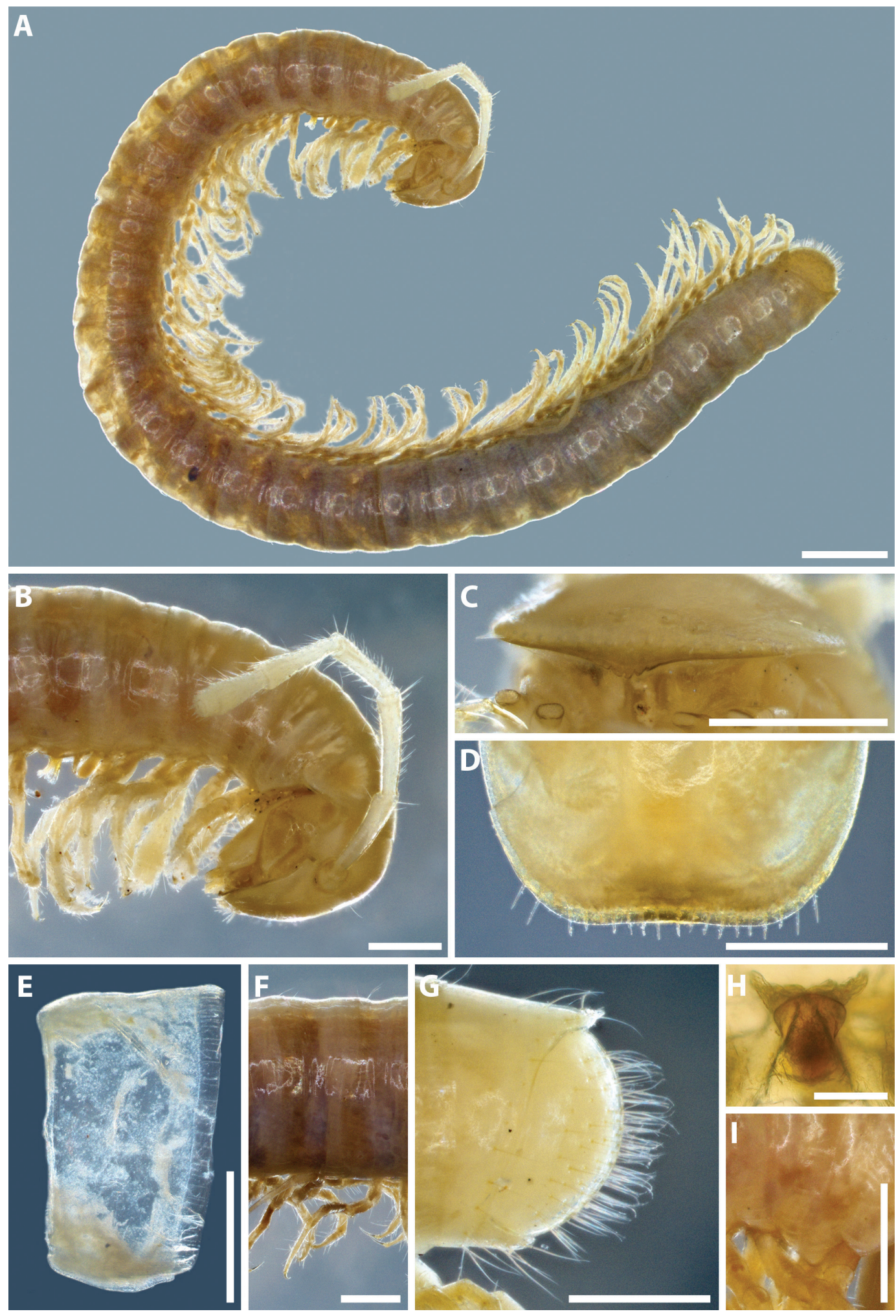

Fig. 4. Stygiiulus gentianae (Strasser, 1971) comb. et stat. nov., $\widehat{O}$ (A-C, E, G) from Grotta [cave] della Vecchia Diga, $\widehat{o}$ topotype (D, H) and $q$ topotype (F, I) (NHMD). A. Habitus, lateral view. B. Anterior part of body, lateral view. C. Labrum, frontal view. D. Labrum, dorsal view. E. Pleurotergum 7, lateral view. F. Mid-body rings, lateral view. G. Telson, lateral view. H. Posterior node of hypopharynx, frontoventral view. I. Lobe of body ring 3, lateral view. Scale bars: A $=1 \mathrm{~mm}$; B-G, I $=0.5 \mathrm{~mm} ; \mathrm{H}=0.1 \mathrm{~mm}$. 


\section{Redescription}

Size AND NUMBER OF BOdy RINGs. Lectotype ô with BRF $36+0+\mathrm{T}, \mathrm{L}=18 \mathrm{~mm}, \mathrm{H}=1.3 \mathrm{~mm}$, paralectotype ㅇ with $\mathrm{BRF} 33+0+\mathrm{T}, \mathrm{L}=16.5 \mathrm{~mm}, \mathrm{H}=1.2 \mathrm{~mm}$; topotype $\hat{\jmath}$ with $\mathrm{BRF} 31+0+\mathrm{T}, \mathrm{L}=20.5 \mathrm{~mm}, \mathrm{H}=$ $1.4 \mathrm{~mm}$; topotype 우 with BRF 31-35+0-1+T, $\mathrm{L}=19-22 \mathrm{~mm}, \mathrm{H}=1.4-1.7 \mathrm{~mm}$; males from Val di Pai with BRF 30-32+1+T, $\mathrm{L}=13 \mathrm{~mm}, \mathrm{H}=1.05-1.1 \mathrm{~mm}$; female from Val di Pai with BRF $30+1+\mathrm{T}$, $\mathrm{L}=17 \mathrm{~mm}, \mathrm{H}=1.3 \mathrm{~mm}$; males from Vecchia Diga with BRF 29-31+0+T, $\mathrm{L}=18-19 \mathrm{~mm}, \mathrm{H}=1.15-$ $1.2 \mathrm{~mm}$, female from Vecchia Diga with BRF $27+1+\mathrm{T}, \mathrm{L}=18.5 \mathrm{~mm}, \mathrm{~h}=1.3 \mathrm{~mm}$. In general, males with BRF 29-36+0-1+T, $\mathrm{L}=13-20.5 \mathrm{~mm}, \mathrm{H}=1.05-1.3 \mathrm{~mm}$; females with BRF $27-36+0-1+\mathrm{T}, \mathrm{L}=$ $16.5-22 \mathrm{~mm}, \mathrm{H}=1.2-1.7 \mathrm{~mm}$.

Colouration (Fig. 4A-B, F-G). Completely pallid, probably as a result of the long alcohol conservation (considering the presence of some colour pattern in the highly similar S. fimbriatus comb. et stat. nov.).

EXternal STRUCTURES. Head with 2 vertigial, $2+2$ supralabral and 16-23 labral setae. Antennae (Fig. 4B) 2.5 times as long as head and 2.4-2.5 times as long as $\mathrm{H}$ in males, and 2.1-2.2 times and 1.8-2.1 times, respectively, in females; antennomere 52.8 times as long as broad. Antennomeres V and VI each with a terminal corolla of large sensilla basiconica bacilliformia; antennomere VII with a terminal corolla of small sensilla basiconica bacilliformia.

MouthParts (Fig. 4C-D, H). Generally similar to those of $S$. fimbriatus comb. et stat. nov., including individuals with edentate labrum (Fig. 4D), as well as individuals with three small but distinct labral teeth (Fig. 4C). Gnathochilarial stipites each with a row of 2-5 rather than up to 10 setae. Posterior node of hypopharynx (Fig. 4C) reduced, with somewhat squarish posterior part.

Collum. Collum as in S. fimbriatus comb. et stat. nov., but with the frontolateral margin only slightly bent outwards. Metazonal striation faint and sparse even on ventral side; setation somewhat shorter than in fimbriatus - around $10 \%$ of $\mathrm{H}$. Tarsus of mid-body legs $2.1-2.3$ times as long as tibia.

TeLson (Fig. 4G). Epiproct very short, not protruding behind caudal contour of paraprocts), ending with a minute hyaline tip turned more or less dorsad. Hypoproct more narrowly rounded compared to the former species, blunt subtriangular in some specimens (regardless of sex).

All remaining external somatic characters as in S. fimbriatus comb. et stat. nov.

Male sexual characters. Male leg-pair 1 (Fig. 5A) similar to the condition in S. fimbriatus comb. et stat. nov., differing in having a proportionately smaller tibial part, apically more sparsely microdentate/ microtuberculate. Male walking legs with more pronounced tibial pads than in S. fimbriatus comb. et stat. nov., these being still visible behind mid-body. Penis (Fig. 5B) as in the former species, but with longer and more tapering terminal lamellae.

Gonopods (Figs 5C, 6). Very similar to those of S. fimbriatus comb. et stat. nov., differing from the latter species mainly by the pro- $(\mathrm{p})$ and mesomere $(\mathrm{m})$ being gradually bent towards one another, rather than both apically turned frontad, and by the smooth rather than ciliate anterior margin of velum (v); also promere in $S$. gentianae comb. et stat. nov. relatively broader, with the external lobe (el) significantly higher than, rather than subequal to, the internal one (il); posterior branch of solenomere $(\mathrm{pb})$ somewhat more robust, anterior branch of solenomere $(\mathrm{ab})$ and posterior hump of opisthomere (ph) of same size and shape as in S. fimbriatus comb. et stat. nov.

Female SeXual CHARActers. Leg-pairs 1 and 2 shorter, 1 also slightly thicker, than following legs. Ventral margin of body ring 3 subtriangular (Fig. 4I). Vulva (Fig. 5D) mostly symmetric, somewhat compressed in the sagittal plane; operculum (op) very large, with a convex apical margin forming several rounded 

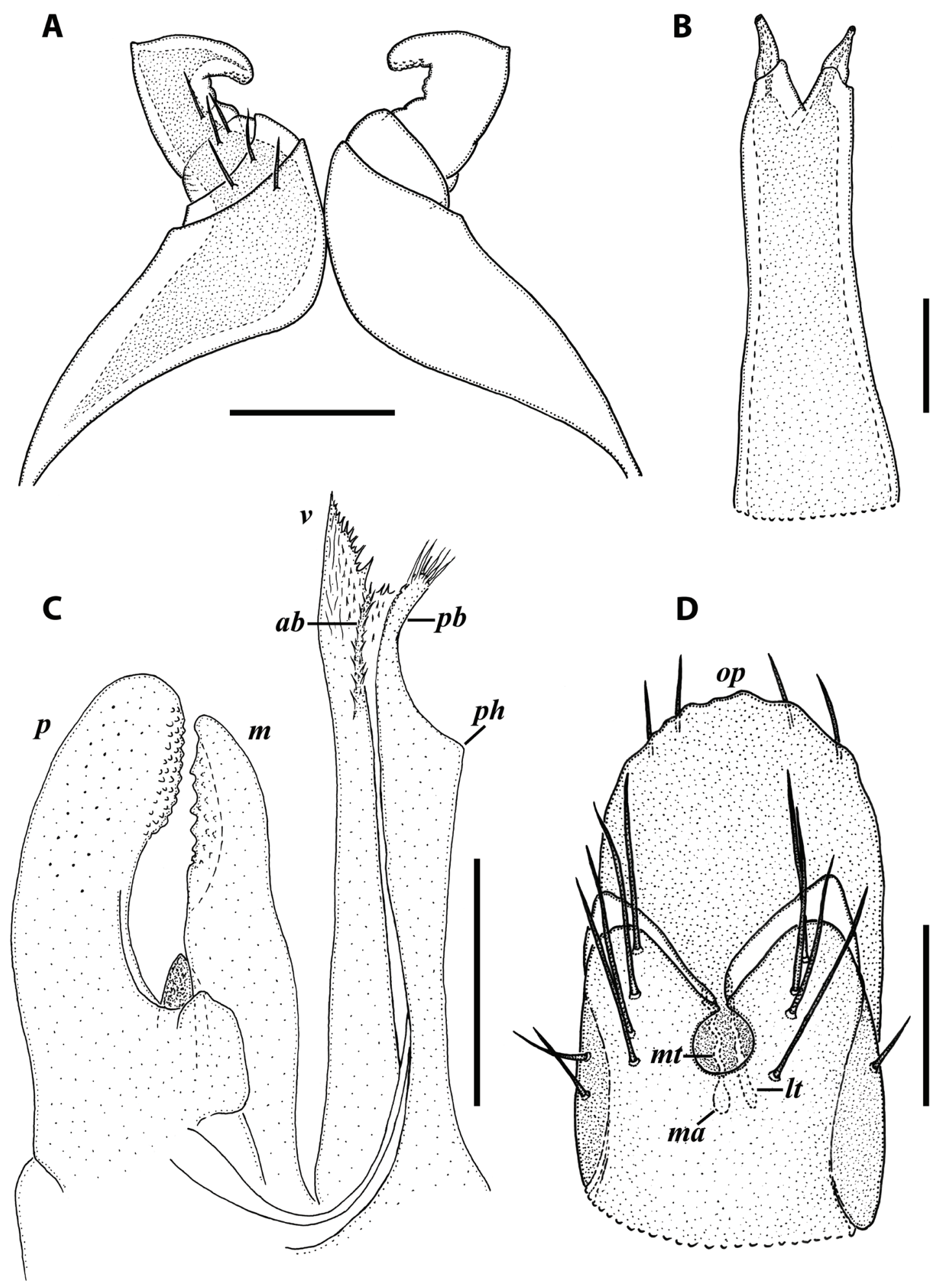

Fig. 5. Stygiiulus gentianae (Strasser, 1971) comb. et stat. nov., § paralectotype (A-B) (MHNG), topotype $\widehat{\sigma}$ (C) (NHMD) and topotype $q$ (D) (NHMD). A. Leg-pair 1, oral view. B. Penis, oral/caudal view. C. Left gonopods, mesal view. D. Left vulva, caudal, somewhat mesal view. Abbreviations: ab = anterior branch of solenomere; $1 \mathrm{t}=$ lateral tube; $\mathrm{m}=$ mesomere; ma = median ampulla; $\mathrm{mt}=$ median tube; $\mathrm{op}=$ operculum; $\mathrm{p}=$ promere; $\mathrm{pb}=$ posterior branch of solenomere; $\mathrm{ph}=$ posterior hump; $\mathrm{v}=$ velum. Scale bars: $\mathrm{A}, \mathrm{C}-\mathrm{D}=0.2 \mathrm{~mm} ; \mathrm{B}=0.1 \mathrm{~mm}$. 
bumps, exceeding bursa by nearly $2 / 5$ of total height of vulva; setation on both bursa and operculum in a similar pattern as in $S$. fimbriatus comb. et stat. nov., but with 1-2 setae on side sclerites in addition. Receptaculum seminis represented by two short and narrow tubes: a mesal one (mt) leading to an ovoid ampulla (ma), and a lateral one (lt) ending without distinct ampulla at bottom.

\section{Distribution}

Known from several caves in the easternmost part of the Venetian Prealps mountain range (Fig. 13, red circles).

\section{Remark}

Strasser (1971a) wrote that this species was found on wet vertical walls (common place for many troglobitic arthropods with mouthpart modifications).

Stygiiulus illyricus (Verhoeff, 1929) comb. nov.

Figs 10B, 11B, 13

Typhloiulus (Stygiiulus) illyricus Verhoeff, 1929: 20-23, fig. 1.

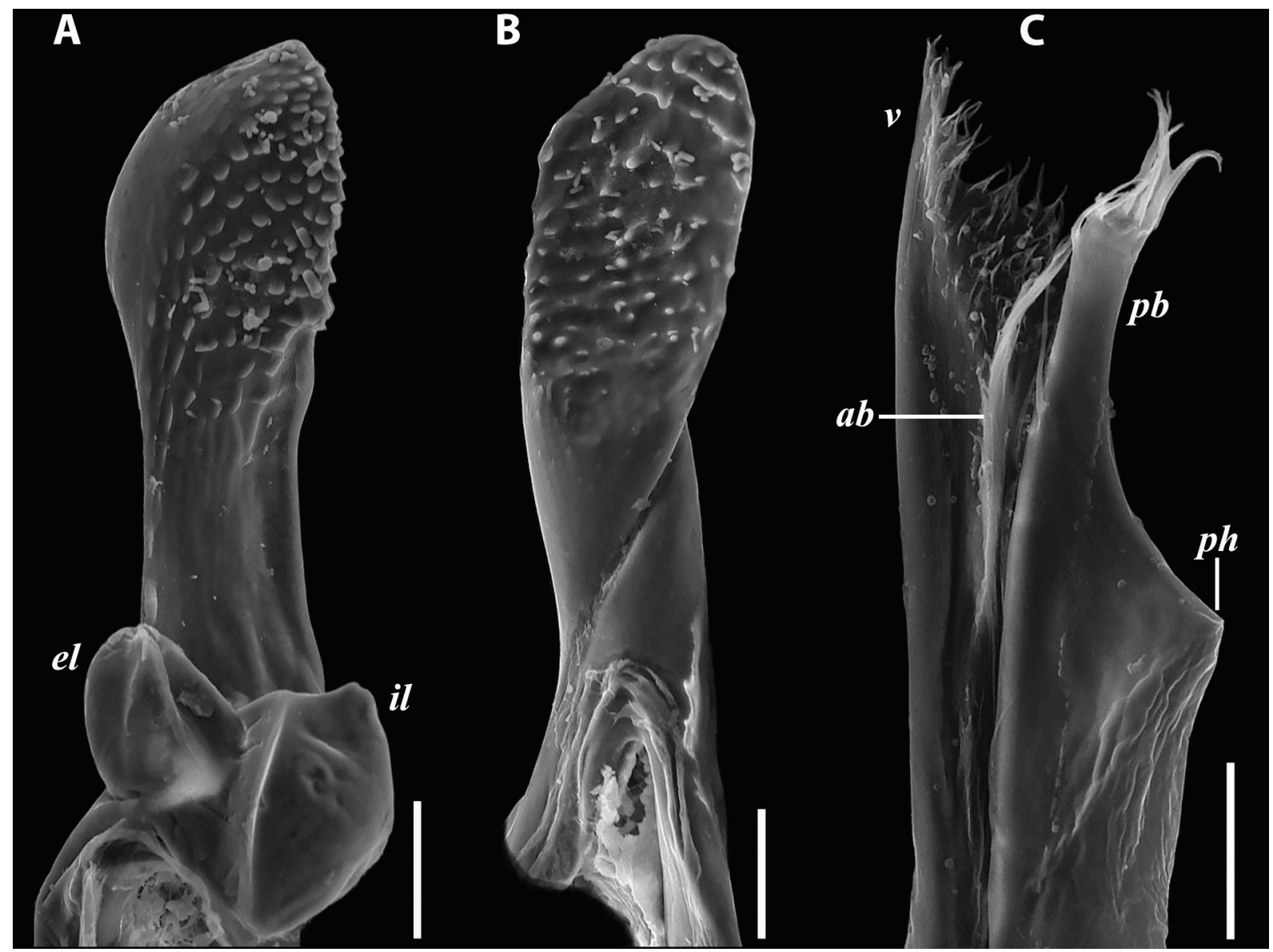

Fig. 6. Stygiiulus gentianae (Strasser, 1971) comb. et stat. nov., § from Grotta [cave] della Vecchia Diga (NHMD). A. Right promere, caudal view. B. Right mesomere, oral view. C. Distal part of left opisthomere, mesal view. Abbreviations: $\mathrm{ab}=$ anterior branch of solenomere; $\mathrm{el}=$ external lobe; $\mathrm{il}=$ internal lobe; $\mathrm{pb}=$ posterior branch of solenomere; $\mathrm{ph}=$ posterior hump; $\mathrm{v}=$ velum. Scale bars $=0.05 \mathrm{~mm}$. 
Typhloiulus (Stygiiulus) illyricus - Manfredi 1932: 81. - Strasser 1962: 20, 35-36, figs 11i, 36-37.

Typhloiulus illyricus - Verhoeff 1930: 17. - Antić et al. 2018: 263, fig. 3.

Typhloiulus illyricus stygis - Verhoeff 1933: 15-17, figs 28-29, syn. nov.

Typhloiulus illyricus var. obscurus - Verhoeff 1933: 17.

Typhloiulus illyricus var. obscura - Wolf 1934-38: 515.

\section{Material examined}

SLOVENIA - 2 topotype juvs; Ocizla, Beško-Ocizeljski System (= Ocizeljska Jama Pit); 19 Apr. 2012; T. Delić leg.; D. Antić det. 2018; IZB • 1 đ̂, 1 क; Dane, Divača, Mejame Pit (= Med jamah, Medjama); 22 Apr. 2014; M. Zagmajster leg.; D. Antić det. 2018; IZB. CROATIA • 1 ô, 1 q; Istria, Ročko polje, Roč, Rabakova Cave; 30 Jun. 2013; D. Šuperina leg.; D. Antić det. 2018; IZB • 1 +; same collection data as for preceding; 16 Apr. 2013; IZB.

\section{Diagnosis}

A species of Stygiiulus with normal mouthparts. Distinguishable from congeners by the combination of certain gonopodal characters (Fig. 10B), viz., a mostly straight promere, a mesomere with the apex bent frontad, and an opisthomere with a small but distinct posterior hump, a broad and deeply serrated velum, and a vestigial posterior solenomeral branch, this being completely fused to the velum.

\section{Descriptive notes}

Antennae. 2.2 times as long as head and ca 1.8 times as long as $\mathrm{H}$ in males, and 1.7 times and ca 1.51.55 times, respectively, in females; antennomere 5 ca 2.4 times as long as broad; antennomeres 2-5 subequal in length, ca 1.3-1.4 times as long as 6.

TARSuS OF MiD-BODY Legs. Ca 2.4 times as long as tibia and ca 2 times as long as apical claw. Mid-body legs ca 1.1 times as long as $\mathrm{H}$ in both sexes.

Female SEXUAL CHARACTERS. Leg-pairs 1 and 2 considerably shorter than, but as thick as, following legs. Vulva (Fig. 11B) slightly compressed in the sagittal plane, mostly symmetric; median cleft deeper than in most congeners; each valve of bursa with several, mostly vertically arranged setae, 1-2 setae on side sclerites; operculum (op) distally markedly thickened, with a concave apical margin, exceeding bursa by slightly more than $1 / 4$ of total height of vulva, medio-laterally with two longitudinal rows of setae each side, with a bunch of setae on each latero-apical corner. Receptaculum seminis consisting of a fine, slightly bent, mesal tube (mt) ending in a small piriform ampulla (ma), and a somewhat shorter lateral tube (lt) ending in an ampulla (la) of similar shape and size as the former one.

\section{Distribution}

Known exclusively from caves and pits in the Istrian Peninsula in Croatia and the northwestern Dinarides in Slovenia (Fig. 13, green squares).

\section{Remark}

From Rabakova Cave, Verhoeff (1933) described the subspecies illyricus stygis, mentioning the possibility that the observed differences between the single male his description was based upon and the typical illyricus were due to periodomorphosis, but he nevertheless opted to give a formal name to the new morph. Indeed, the gonopods he drew seem to be underdeveloped (see Verhoeff 1933: 20, fig. 28). Fortunately, we examined here one adult male from Rabakova Cave, whose gonopods appeared completely identical to the gonopods of the typical illyricus. We were even luckier to find that one of the juveniles from the type locality of the typical illyricus was a subadult male with unmodified first pair of legs. The gonopods of this subadult male are very similar to Verhoeff's (1933) drawing of the gonopods of the subspecies stygis. 
Based on these observations, it is clear that Verhoeff's stygis was actually a non-adult male or "JuniorMännchen" [junior male] - a term coined by Strasser (1971b), referring to typhloiulinine males with almost fully developed gonopods, but with non-modified first pair of legs and other, less conspicuous, underdeveloped external somatic structures (see also Vagalinski et al. 2015). We thus consider here S. illyricus stygis syn. nov. as a junior subjective synonym of the typical $S$. illyricus comb. nov.

Stygiiulus insularis (Strasser, 1938) comb. nov.

Figs $10 \mathrm{C}, 11 \mathrm{C}, 13$

Typhloiulus insularis Strasser, 1938: 399-402, fig. 10.

Typhloiulus insularis - Vagalinski et al. 2015: 340. - Antić et al. 2018: 263-264; figs 5-6, 18c.

\section{Material examined}

CROATIA -1 topotype $\widehat{\delta}$; Island of Cres, Beli, Petričevići, Čampari Pit; 8 Apr. 2001; R. Ozimec and B. Jalžić leg.; IZB 11 topotype $q$; same collection data as for preceding; 20 Oct. 2000; CBSS.

\section{Diagnosis}

A species of Stygiiulus stat. nov. with normal mouthparts. Distinguishable from congeners by its smaller body $(\mathrm{L}=10-16 \mathrm{~mm})$ and shorter legs in relation to $\mathrm{H}$, by the ozopores being placed on or right behind the pro-metazonal suture instead of at considerable distance behind it, and in several aspects of gonopod structures (Fig. 10C), viz., ridge- rather than knob-like internal lobe of the promere, spoon-shaped mesomere, rather robust opisthomere without a posterior hump (the latter shared with S. seewaldii comb. nov.), long basal spine at flagellum channel (sometimes present in $S$. rotundatus comb. et stat. nov. and S. fimbriatus comb. et stat. nov.), and the presence of a distinct distal outgrowth (do) on velum (seen also in S. seewaldi comb. nov. and S. tobias comb. nov.).

\section{Descriptive notes}

ANTENNAE. 1.6 times as long as head and 1.65 as long as $\mathrm{H}$ in the male, and 1.35 and 1.3 times, respectively, in the female; antennomere $5 \mathrm{ca} 1.6$ as long as broad; antennomeres 2 and 5 subequal in length, ca 1.3 times as long as 3 and 4 , and 1.5 times as long as 6 .

TARSUS OF MID-BODY LEGS. Ca 2.7 times as long as tibia and ca 3.7 times as long as apical claw. Mid-body legs 1.25 times as long as $\mathrm{H}$ in the the male and 0.7 times in the female.

Female sexual characters. Leg-pairs 1 and 2 visibly longer and thicker than following legs. Vulva (Fig. 11C) of nearly equal width in both the sagittal and the transverse planes, mostly symmetric; bursa with a narrow median cleft; each valve distally with a vertical row of 2-4 setae; operculum (op) proximally broad, distally abruptly narrowing, ending with a more or less straight apical margin, exceeding bursa by ca $1 / 8$ of total height of vulva, disto-laterally with one vertical row of setae each side. Receptaculum seminis consisting of a very short and narrow, somewhat bent, median tube (mt) leading to a minute piriform ampulla (ma), and a slightly longer, mostly straight, lateral tube (lt) ending in a minute spherical ampulla (la).

\section{Distribution}

Known only from its type locality, the Čampari Pit on the island of Cres in Croatia (Fig. 13, red square).

\section{Remarks}

Strasser's (1938) description of S. insularis comb. nov. was based upon four females only. Due to the absence of male specimens, this species has remained enigmatic for 80 years, until Antic et al. (2018) described the 
first male and, according to the gonopod structure, hypothesized this species could belong to Stygiiulus stat. nov. Here we follow that assumption, which is further supported by the vulval structure, and formally transfer insularis to the genus Stygiiulus stat. nov. However, this species is obviously different externally compared to other Stygiiulus stat. nov. members, and is characterized by a smaller body and proportionatelly shorter antennae, as well as by a more anterior position of the ozopores. And while these external differences (or some of them) may be connected with its currently unknown ecology rather than with its phylogenetic affinities, certain gonopod characters, viz., the aforementioned spoon-like shape of the mesomere and the robustness of the opisthomere, plus a ridge- rather than knob-like internal lobe of the promere leave some doubts about the exact systematic position of insularis. But since the general gonopod conformation in this species is much more similar to other Stygiiulus stat. nov. than to any other typhloiulinine/blind leptoiulinine genus, we have opted here to formally place this interesting taxon in the aforementioned genus. Nevertheless, we are aware that in the future this tiny species could find its place in another (new) genus.

The Čmpari Pit is also the type locality of another julid species, the pachyiulinine Chersoiulus ciliatus Strasser, 1938. Both $S$. insularis comb. nov. and C. ciliatus are strict endemics of this pit and are listed as critically endangered species (CR) in the Red Book of the Croatian cave dwelling fauna (Ozimec et al. 2009).

Stygiiulus maximus (Verhoeff, 1929) comb. nov.

Fig. 10D

Mesoporoiulus maximus Verhoeff, 1929: 19-20, fig. 2.

Typhloiulus (Stygiiulus) maximus - Verhoeff 1930: 9, 12-13, figs 1-2. — Manfredi 1932: 81.

Typhloiulus (Mesoporoiulus) maximus - Pretner \& Strasser 1931: 87.

Typhloiulus maximus var. longicauda Strasser, 1962: 59-60, fig. 71.

Typhloiulus maximus var. maximus - Strasser 1962: 59, fig. 72.

Typhloiulus maximus - Attems 1949: 145. — Strasser 1971a: 14. — Vagalinski et al. 2015: 342-343.

not Typhloiulus tobias - Attems 1927: 250-251, figs 352-354.

\section{Diagnosis}

A species of Stygiiulus stat. nov. with normal mouthparts. Distinguishable from congeners by the combination of certain gonopodal characters (Fig. 10D), viz., a mostly straight pro- and mesomere, and an opisthomere with a faint and blunt posterior hump, a marginally broad (not tapering) and deeply serrated velum, and a solenomere with both the anterior and the posterior solenomeral branch being well developed and clearly discernible.

\section{Distribution}

This species has the widest distribution of all representatives of the genus Stygiiulus stat. nov. Known from numerous caves, as well as epigean habitats, ranging from the Julian Alps in the east, across the southern parts of the Carnic Alps Range, through the Venetian Prealps, all the way to the Piave River in the west (Fig. 13, pink squares).

\section{Remark}

Attems (1927: 250, 251, figs 352-354) gave a short description and drawings of what he thought was already described as $S$. tobias comb. nov. from Monte Cavallo (Lombardy). Just two/three years later, Verhoeff (1930) described another blind julid, S. maximus comb. nov., from a cave in the same area. What is evident from the gonopod drawings of both Attems and Verhoeff alone - that is that Attems' (1927) record actually refers to $S$. maximus comb. nov. - was already confirmed by Strasser (1962: 60) based on re-examination of the specimens from Monte Cavallo. 
Stygiiulus montellensis (Verhoeff, 1930) comb. nov.

Figs 7, 13

Typhloiulus (Stygiiulus) montellensis Verhoeff, 1930: 14-16, figs 4-5.

Typhloiulus (Stygiiulus) montellensis - Manfredi 1932: 81. — Strasser 1962: 57-58, figs 5, 11j, 66-67. Typhloiulus montellensis - Wolf 1934-38: 516. - Vagalinski et al. 2015: 343.

Typhloiulus montebellensis (sic!) - Attems 1949: 145.

Typhloiulus (Stygiiulus) montellensis montellensis - Paoletti 1978: 108.

Typhloiulus montellensis montellensis - Minelli 1985: 10.

\section{Diagnosis}

A species of Stygiiulus stat. nov. with normal mouthparts. Differs from its most similar congener, S. rotundatus comb. et stat. nov., by the distal part of mesomere (Fig. 7B, $\mathrm{m}$ in Fig. 7A) being clavate, ending with a broad, flat apex, vs the same being fronto-caudally compressed, ending with a rounded apex in the latter species; and by the vulval operculum being broader and with a smooth and gently concave apical margin, vs the same being relatively narrow, with an uneven, coarsed/undulating apical margin in $S$. rotundatus comb. et stat. nov.

\section{Material examined}

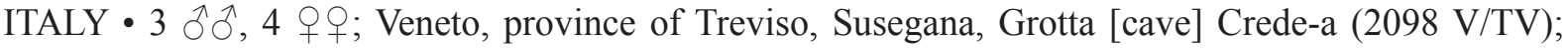
175 m a.s.1.; 20 Feb. 1993; E. Piva leg.; NHMD • $2 \widehat{\jmath}, 1$ q, 1 juv.; Veneto, province of Treviso, Massiccio del Grappa Mtn, Cavaso del Tomba, Speoncia [cave] del Diaol (1811 V/TV); 45 50'49" N, 1154'26.4" E; 275 m a.s.1.; 17 Oct. 1999; E. Piva leg.; NHMD.

\section{Descrptive notes}

AntenNAE. 1.85-2.2 times as long as head and 1.5-2.1 times as long as $\mathrm{H}$ in males, and 2-2.1 and 1.31.5 times, respectively, in females; antennomere $52-2.3$ times as long as broad; antennomeres 2 and 3 subequal in length, 1.1-1.2 times as long as 4 and 5, and 1.2-1.4 times as long as 6. Tarsus of mid-body legs $2-2.3$ times as long as tibia and 3-4 times as long as apical claw. Mid-body legs from equal to, to 1.4 times as long as, $\mathrm{H}$ in males, and $0.9-1.1$ times in females.

FeMALE SEXUAL CHARACTERS. Legs 1 and 2 slightly shorter but not thicker than following legs. Vulva (Fig. 7C) symmetric, somewhat compressed in the sagittal plane; bursa with a rather broad cleft, each valve distally with several setae in a vertical row; operculum (op) large, subquadrangular, with a slightly convex, smooth apical margin, exceeding bursa by ca $1 / 3$ of total height of vulva, distally with several setae each side. Receptaculum seminis represented by a relatively long, narrow, slightly bent, mesal tube (mt) leading to a minute piriform ampulla (ma), and an even finer, shorter, twisted, lateral tube (lt) forming an ovoid ampulla (la) at bottom.

\section{Distribution}

Known from several caves as well as epigean habitats in a small area on the southern side of the Venetian Prealps' foothill, north of Treviso. All but one record come from the right side of the Piave River (Fig. 13, yellow squares).

Stygiiulus rotundatus (Strasser, 1962) comb. et stat. nov.

Figs 8-9, 13

Typhloiulus (Stygiiulus) montellensis rotundatus Strasser, 1962: 57-58, figs 68-69.

Typhloiulus montellensis rotundatus - Minelli 1985: 10. — Vagalinski et al. 2015: 343. 


\section{Diagnosis}

A species of Stygiiulus stat. nov. with normal mouthparts. Differs from its most similar congener, S. montellensis comb. nov. by the distal part of mesomere being fronto-caudally compressed, ending with a rounded apex, vs the same being clavate, ending with a broad and flat apex in the latter species; and by the vulval operculum being relatively narrow, with an uneven, coarsed/undulating apical margin, vs the same being broader and with a smooth and gently concave apical margin in S. montellensis comb. nov.

\section{Material examined}

Lectotype (designated here)

ITALY • $\widehat{\top}$ 20-41-71 slide preparation; Veneto, province of Treviso, Refrontolo, Busa di Fave [Bus de le Fave Cave]; 7 May 1959; gonopods, flanges of pleurotergum 7; MHNG-ARTO-27001.

A

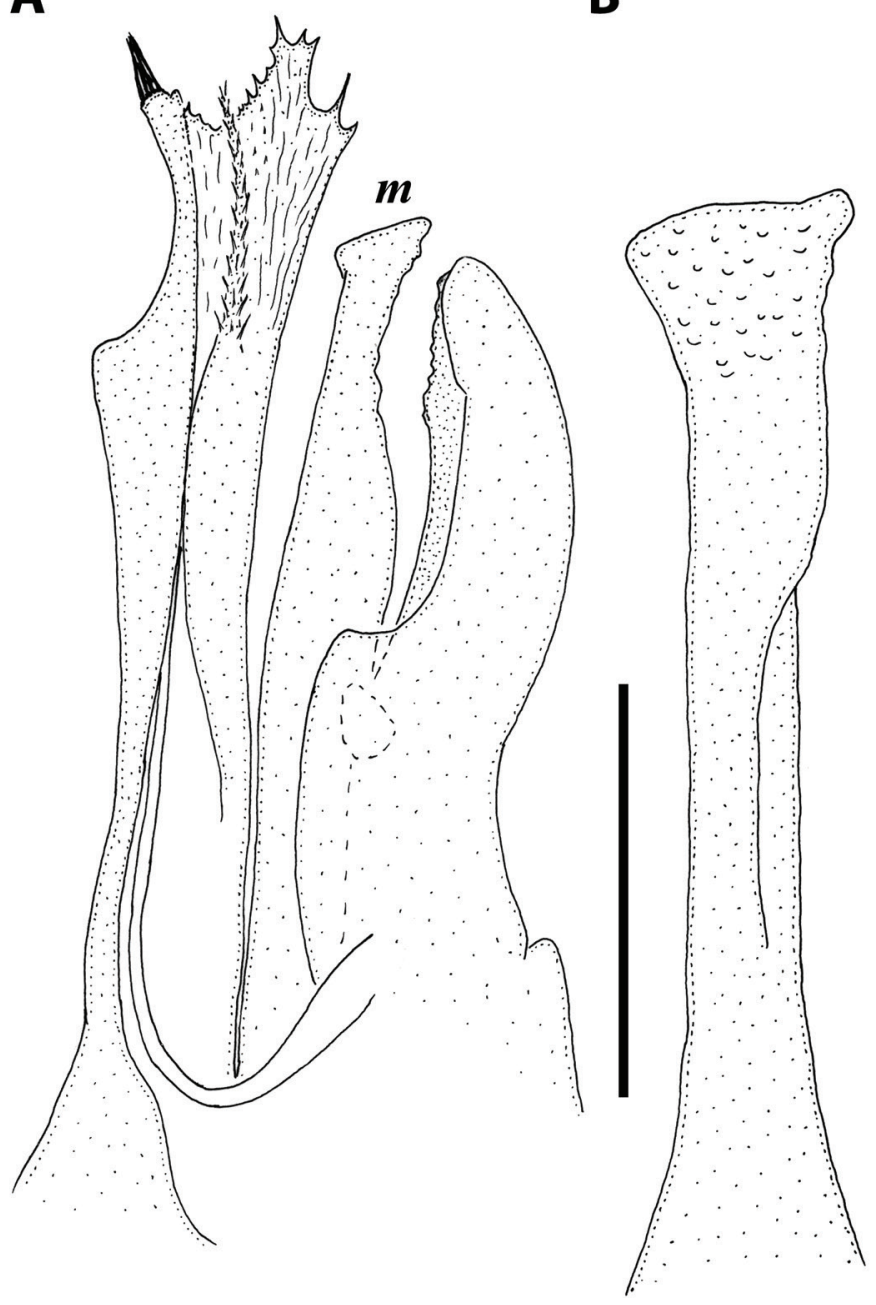

C

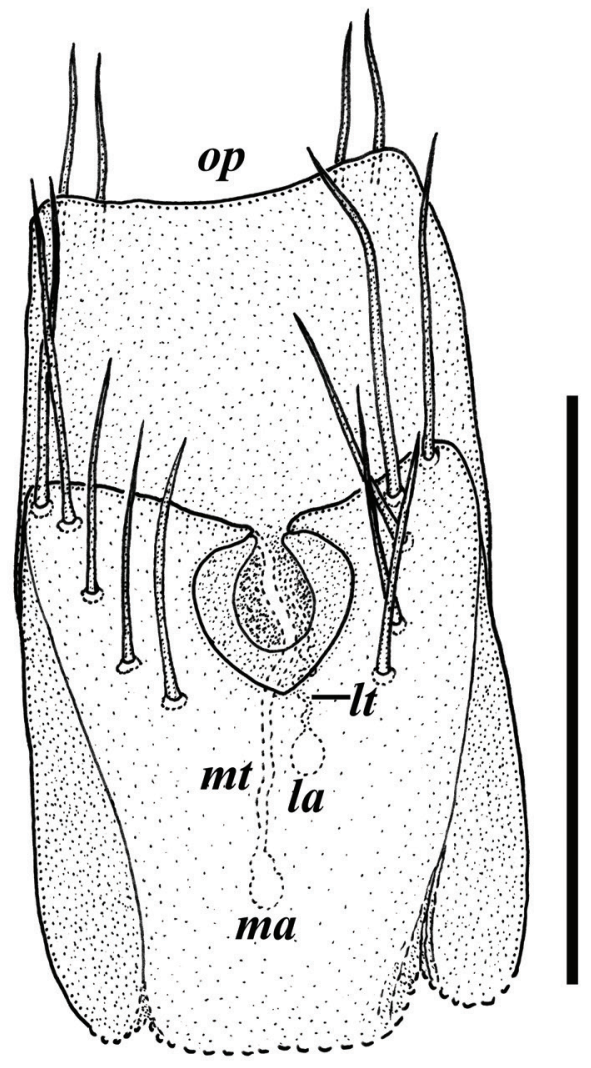

Fig. 7. Stygiiulus montellensis (Verhoeff, 1930) comb. nov., $\widehat{o}$ from Grotta [cave] Crede-a (NHMD). A. Right gonopods, mesal view. B. Right mesomere, oral view. C. Left vulva, caudal, slightly mesal view. Abbreviations: $1 \mathrm{a}=$ lateral ampulla; $1 \mathrm{t}=$ lateral tube; $\mathrm{m}=$ mesomere; $\mathrm{ma}=$ median ampulla; $\mathrm{mt}=$ median tube; op = operculum. Scale bars: A-B $=0.2 \mathrm{~mm} ; \mathrm{C}=0.3 \mathrm{~mm}$. 


\section{Paralectotypes}

ITALY • 1 ऽ 28-43-74 slide preparation; same collection data as for lectotype; gonopods, antenna, legs 1, 2, 3, 7, mouthparts, flanges of pleurotergum 7; MHNG-ARTO-27002 • 1 ○ 19.5-41-63 slide preparation; same collection data as for lectotype; gonopods, flanges of pleurotergum 7; MHNG-ARTO-27003.

\section{Other material}

ITALY • 1 đ; Veneto, province of Treviso, San Pietro di Feletto, Grotta [cave] di Foltran (1251 V/ TV); 8 Aug. 1961; Paoletti leg.; specimen unbroken; MHNG • 1 đิ 23-43-75 slide preparation; same collection data as for preceding; 8 Aug. 1971; gonopods, antenna, flanges of pleurotergum 7; MHNGARTO-27004 • 1 त 17-38-61 slide preparation; same locality; date unknown; gonopods, antenna, flanges of pleurotergum 7; MHNG-ARTO-27005 • 1 ○ 26-46-81 slide preparation; Veneto, province of Treviso, Farra di Soligo, Grotta [cave] di Collagù (1225 V/TV); 30 Oct. 1966; gonopods, antennae,

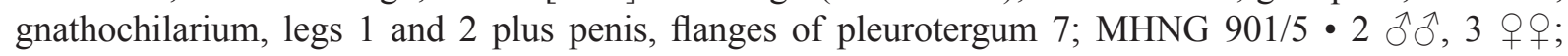
Veneto, province of Treviso, San Pietro di Feletto, La Bora Cave (1252 V/TV); 110 m a.s.1.; 9 Mar. 2008; D. Bianco and E. Piva leg.; H. Enghoff det. 2013; NHMD.

\section{Comment}

The original description of Strasser (1962) does not contain information on the number of type specimens and a holotype has not been designated. However, it can be inferred from text that the type locality is the cave Bus de le Fave near the village of Refrontolo, province of Treviso, and the material the description is based upon was collected on $7^{\text {th }}$ May and $10^{\text {th }}$ June 1959. The label data of three of the examined MHNG slides contain the same toponym and date. Since the position of the right gonopods in slide " $\widehat{\gamma}$ 20-41-71" is most similar to the aspect shown in Strasser's (1962: fig. 68) description, we here designate that same slide as lectotype, in order to stabilize the nomenclature of the species under Article 74.1 of the ICZN.

\section{Redescription}

Size AND NUMBER OF BODY RINGS. $\hat{\jmath}$ ô with BRF $42-49+1+\mathrm{T}, 1=17-28 \mathrm{~mm}, \mathrm{H}=1.3-1.4 \mathrm{~mm}$; $q$ with BRF $50+0+\mathrm{T}, \mathrm{L}=27.5-33.5 \mathrm{~mm}, \mathrm{H}=1.54-1.92 \mathrm{~mm}$.

Colouration (Fig. 8). Mostly light grey, apparently further faded from the alcohol conservation, with a brownish transverse band at posterior parts of metazonae; head, telson and legs brown.

EXternal StRUCtURes. $2+2$ supralabral setae (one $q$ with 5), spread in more or less equal distances from one another, and 12-16 labral setae. Antennae (Fig. 8B) 2-2.4 times as long as head and ca 1.5 as long as $\mathrm{H}$ in males, and ca 2 times and 1.3 times, respectively, in females; antennomere 52.5 times as long as broad; antennomeres 3-5 subequal in length, somewhat shorter than 2 and ca 1.3 times longer than 6 .

MouthPARTS. Of normal julid type. Labrum tridentate. Lingual lamellae each with 2-3 basal, 1 median and 1 distal seta in a longitudinal row. Promentum markedly elongated, separating the lamellae in about their proximal $1 / 2$. Gnathochilarial stipites each with a group of several short setae medially, just under lingual lamellae.

Collum. Completely smooth. Prozonae smooth. Metazonae with well-developed striation only ventrally, dorsally and laterally with short and shallow striae; length of setae from $9 \%$ (in mid-body and hind body rings) to $25 \%$ (in anterior-most rings) of $\mathrm{H}$.

OzOPORES. Placed behind pro-metazonal suture at $\mathrm{ca}^{2 / 5}$ (in more anterior rings) to almost $1 / 2$ (in more posterior rings) of metazonal length measured from front to back. Tarsus of mid-body legs 1.9-2.2 times 
as long as tibia and 2.7-3.6 times as long as apical claw. Mid-body legs $1-1.2$ times as long as $\mathrm{H}$ in males, and ca 0.85 times in females.

Telson (Fig. 8E). Epiproct stout, wedge-like, more or less straight, ending with a short and blunt hyaline tip directed completely distad or slightly dorsad, not reaching level of longest paraproctal setae. Hypoproct from narrowly rounded to blunt triangular, not protruding past rear contour of paraprocts in
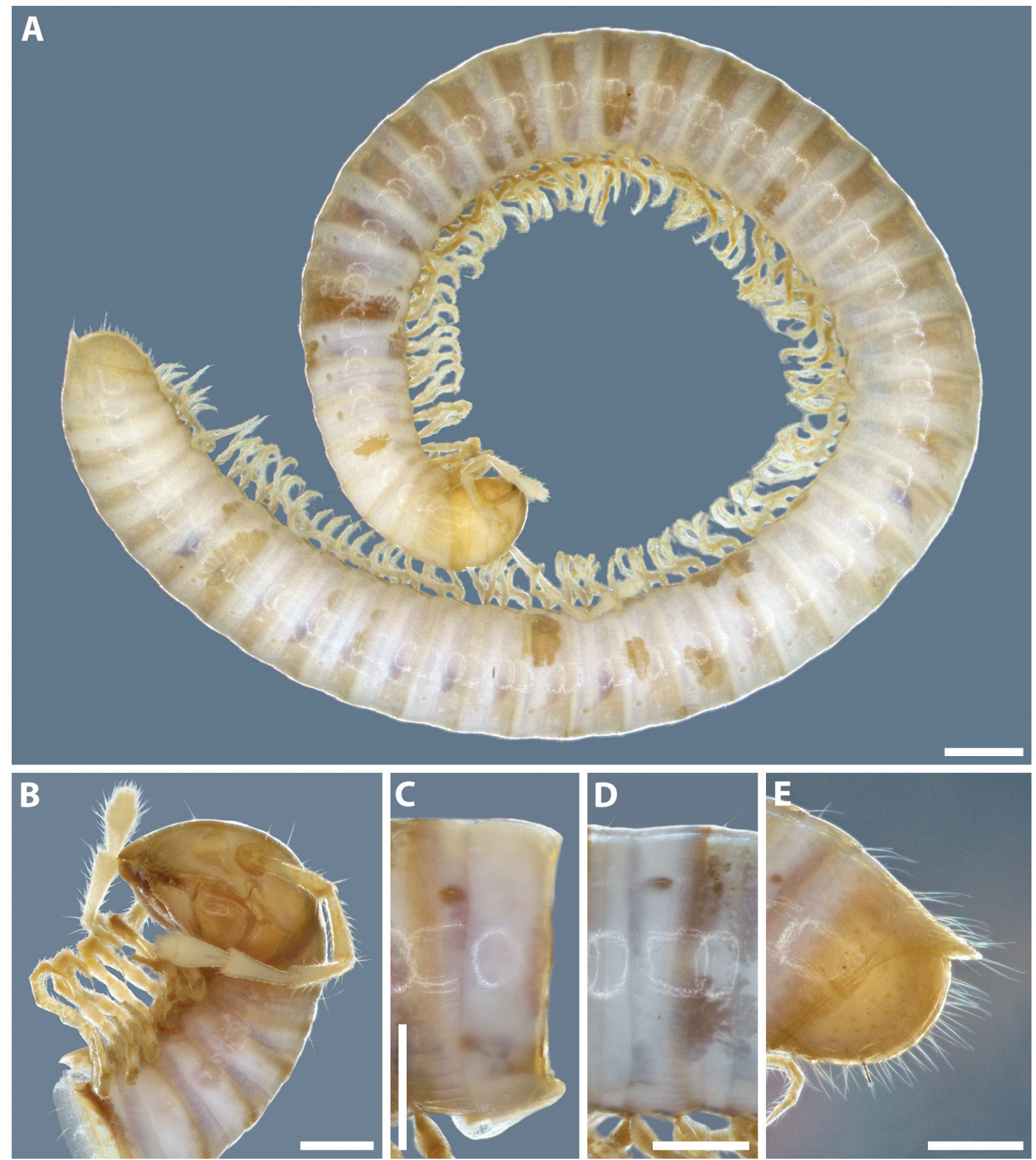

Fig. 8. Stygiiulus rotundatus (Strasser, 1962) comb. et stat. nov., $\uparrow(\mathrm{A})$ and $\widehat{\partial}$ (B-E) from La Bora Cave (NHMD). A. Habitus, lateral view. B. Anterior part of body, lateral, slightly ventral view. C. Pleurotergum 7, lateral view. D. Mid-body rings, lateral view. E. Telson, lateral view. Scale bars: A $=1 \mathrm{~mm} ; \mathrm{B}-\mathrm{E}=0.5 \mathrm{~mm}$. 
both sexes, bearing 5-10 submarginal and a pair of median parabasal setae. Paraprocts moderately to densely covered with long setae, without distinct rows of shorter setae along caudal margins.

MALE SEXUAL CHARACTERS. Leg-pair 1 (9A) rather compact, three-segmented hooks oriented towards one another, with relatively small, apically microdentate/micropapillate tibial outgrowths, without tarsal remnants. Leg-pairs 2 and 3 somewhat ticker than following legs. Tibial adhesive pads well developed until about mid-body, first several leg-pairs with a less strongly pronounced postfemoral pad in addition. Pleurotergum 7 (Fig. 8C) with considerably expanded ventral margins forming broad and rounded lobes. Penis (Fig. 9B) long, in situ visible behind coxae 2, basally broad, abruptly narrowing until $1 / 3$ of its length, then running parallel-sided, before barely widening distally, ending with short, diverging apical lobes bearing small, pointed, terminal lamellae turned completely laterad.

Gonopods (Fig. 9C-D). In situ completely concealed in gonopodal sinus and between lobes of pleurotergum 7. Mesomere slightly exceeding promere, both being considerably shorter than opisthomere. Promere (p in Fig. 9C) slender oar-shaped, bent somewhat caudad, forming a narrowly rounded mesoapical corner; caudal face distally not too densely microsquamose/macropapillate, basally with a strongly pronounced, ridge-like internal lobe and a smaller, leaf-like external lobe. Mesomere (Fig 9D, $\mathrm{m}$ in Fig. 9C) narrow spade-like, with a flattened or broadly rounded apex directed distad; caudal face distally deeply concave and sparsely micropapillate. Opisthomere (Fig. 9C) relatively slender, with a strongly pronounced posterior hump (ph); velum (v) very broad, with a smooth frontal and a deeply serrated apical margin; solenomere with a rather stout, apically ciliate posterior branch (pb) and a very fine and pointed anterior branch (ab), shortly ciliate all along.

Female SeXUal Characters. Leg-pairs 1 and 2 somewhat thicker and slightly longer than following legs. Vulva (Fig. 9E) mostly symmetric: only mesal valve of bursa somewhat broader than lateral one; bursa slightly compressed on sides, with a relatively broad and shallow median cleft; each valve distally with one vertical row of several setae, side sclerites each with a pair of setae; operculum (op) somewhat narrowing distad, with an uneven, undulating apical margin exceeding bursa by ca $1 / 3$ of total height of vulva, distally with a group of several setae each side. Receptaculum seminis consisting of two very short and narrow, somewhat folded tubes: a mesal (mt) and a lateral one (lt), both ending in two ovoid ampullae, the lateral one (la) being considerably larger than the mesal one (ma).

\section{Distribution}

Known from several caves in a small area on the southern side of the Venetian Prealps' foothill, north of Treviso. All records come from the left side of the Piave River (Fig. 13, blue squares).

Stygiiulus seewaldi (Strasser, 1967) comb. nov.

Figs 10E, 13

Alpityphlus seewaldi Strasser, 1967: 146-150, figs 4-9.

Typhloiulus seewaldi - Fritsch 1998: 149-150, 16. — Vagalinski et al. 2015: 346.

\section{Diagnosis}

A species of Stygiiulus stat. nov. with normal mouthparts. Easily distinguishable from congeners by its specific gonopod conformation (Fig. 10E) including a narrow, pointed velum considerably exceeding the solenomere and bearing a small, pointed, distal outgrowth (do) (the latter structure present also in S. insularis comb. nov. and in (some specimens of) S. tobias comb. nov.), in combination with the complete absence of a posterior hump on the opisthomere. Also outstanding by the small and rounded internal lobe of the promere, which is positioned close to promeral base. 

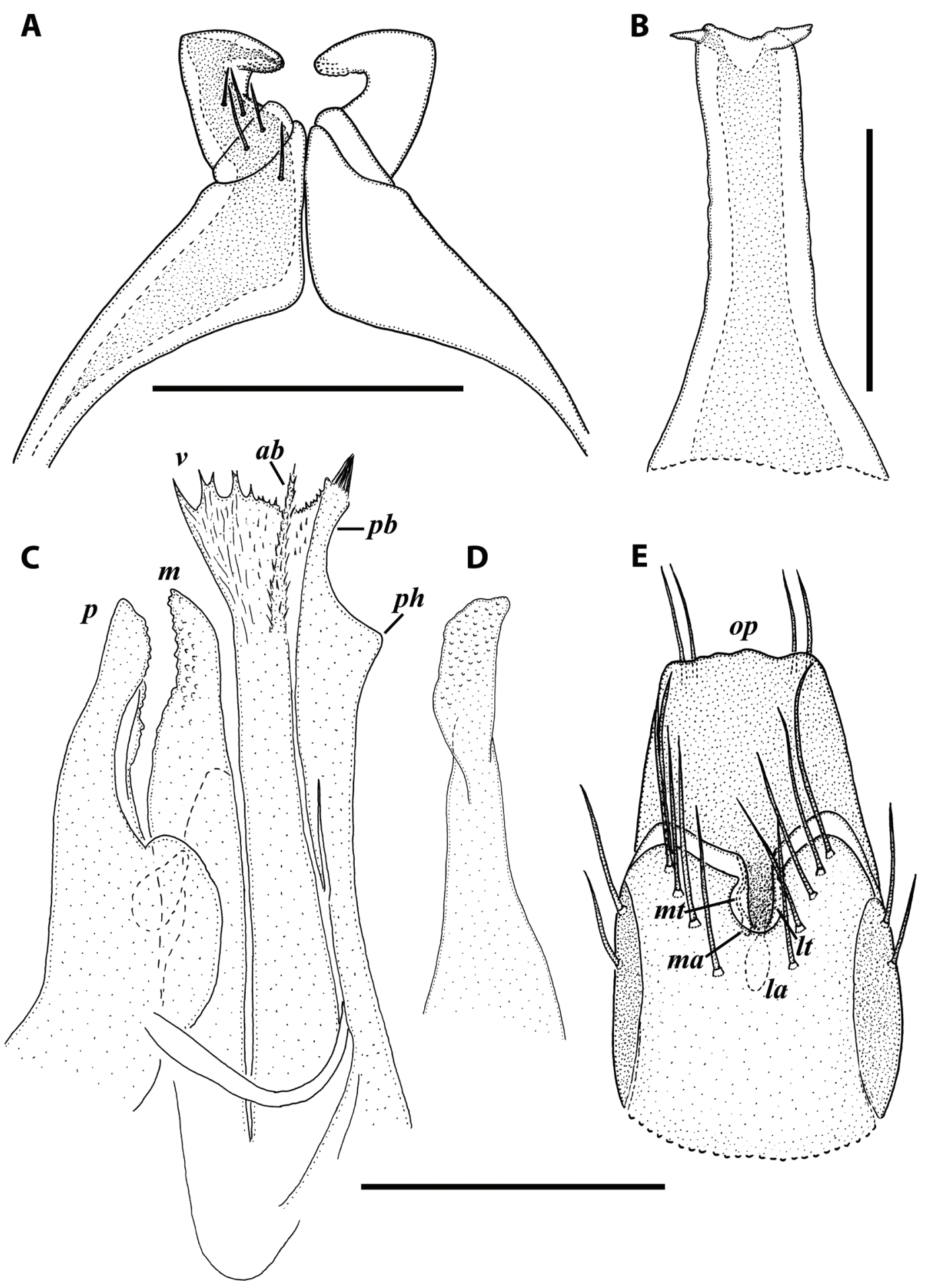

Fig. 9. Stygiiulus rotundatus (Strasser, 1962) comb. et stat. nov., paralectotype $\widehat{\partial}$ (A) (MHNG), $\hat{\sigma}$ from Grotta [cave] di Collagù (B) $(\mathrm{MHNG})$ and $\widehat{\partial}(\mathrm{C}-\mathrm{D})$ and $q$ (E) from La Bora Cave (NHMD). A. Leg-pair 1, oral view. B. Penis, oral/caudal view. C. Right gonopods, mesal view (inverted). D. Left mesomere, oral view. E. Left vulva, caudal, somewhat mesal view. Abbreviations: $a b=$ anterior branch of solenomere; $1 \mathrm{a}=$ lateral ampulla; $1 \mathrm{t}=$ lateral tube; $\mathrm{m}=$ mesomere; $\mathrm{ma}=$ median ampulla; $\mathrm{mt}=$ median tube; $\mathrm{op}=$ operculum; $\mathrm{p}=$ promere; $\mathrm{pb}=$ posterior branch of solenomere; $\mathrm{ph}=$ posterior hump; $\mathrm{v}=$ velum. Scale bars: $\mathrm{A}=0.4 \mathrm{~mm} ; \mathrm{B}=0.2 \mathrm{~mm} ; \mathrm{C}-\mathrm{E}=0.3 \mathrm{~mm}$. 


\section{Distribution}

Germany, Upper Bavaria, Berchtesgadener Land, Untersberg Massif, Cave Hollerloch (the type locality); Austria, Dachstein Mts, tunnel Warmwasserstollen near Lake Hallstatt and Obere Brangrabenhöhle Cave (Fritsch 1998) (Fig. 13, orange squares).

\section{Remark}

Fritsch (1998) listed this species under the genus Typhloiulus, relying on J.-P. Mauriès' opinion expressed in a letter to him. According to Mauriès who studied material of seewaldi, the erection of the genus Alpityphlus by Strasser (1967) was unfounded, the species being a member of Stygiiulus, at that time a subgenus of Typhloiulus. A similar view was expressed by Antić et al. (2017, 2018), but without a formal transfer to Stygiiulus. Based on the detailed original drawings we fully agree on that view, hence the new name combination is formalized here.

Stygiiulus tobias (Berlese, 1886) comb. nov.

Figs 10F, 11D, 13

Julus (Typhloiulus) Tobias Berlese, 1886: 98-99, tab. XIII, figs 20-23.

Typhloiulus (Iulus, Mesoporoiulus) Tobia (tobias) - Manfredi 1932: 81.

Typhloiulus tobias - Wolf 1934-38: 516. — Vagalinski et al. 2015: 345-346.

Typhloiulis (sic!) tobias - Boldori 1936: 113.

Typhloiulus Tobia (sic!) - Boldori 1937: 11.

Typhloiulus (Mesoporoiulus) tobias - Verhoeff 1930: 16-17, fig. 3. - Strasser 1962: 38-39, figs 11f, 45-46.

Typhloiulus Tobias - Conci 1951: 44.

Typhloiulus tobias var. fuscus Manfredi, 1953a: 139.

? Typhloiulus tobias pygmaeus Manfredi, 1953b: 100.

Typhloiulus tobias fuscus - Manfredi 1953b: 101.

\section{Diagnosis}

A species of Stygiiulus stat. nov. with normal mouthparts. Clearly distinguishable from congeners by the very distinctive structure of the opisthomere (Fig. 10F) including a right- to acute-angled posterior hump pointing distad, a large, (sometimes) bipartite velum (with a posteriorly positioned distal outgrowth (do), this being much less prominent than in $S$. insularis comb. nov. and S. seewaldi comb. nov.), with the main part being mostly smooth (barely serrated), and a solenomere distally forming a stout anterior and a much more slender posterior branch, both apically finely ciliate; some specimens with a minute third thumb-like branch basally to the posterior branch. In addition, this species (except for its dubious subspecies T. t. pygmaeus, see below) differs from all other Stygiiulus stat. nov. species by the presence of a very long and upwards curved epiproct.

\section{Material examined}

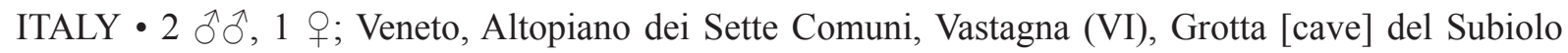
(135 V/VI); 169 m a.s.1.; 4 Mar. 1990; G. Peretto and E. Piva leg.; H. Enghoff det. 2013; NHMD.

\section{Descriptive notes}

Antennae. 2.2-2.4 times as long as head and $1.65-1.7$ as long as $\mathrm{H}$ in males, and 1.9-2 and 1.31.4 times, respectively, in females; antennomere 5 2.6-2.9 times as long as broad; antennomeres 2, 3 and 5 subequal in length, slightly longer than 4 , and 1.4-1.5 times as long as 6 . 

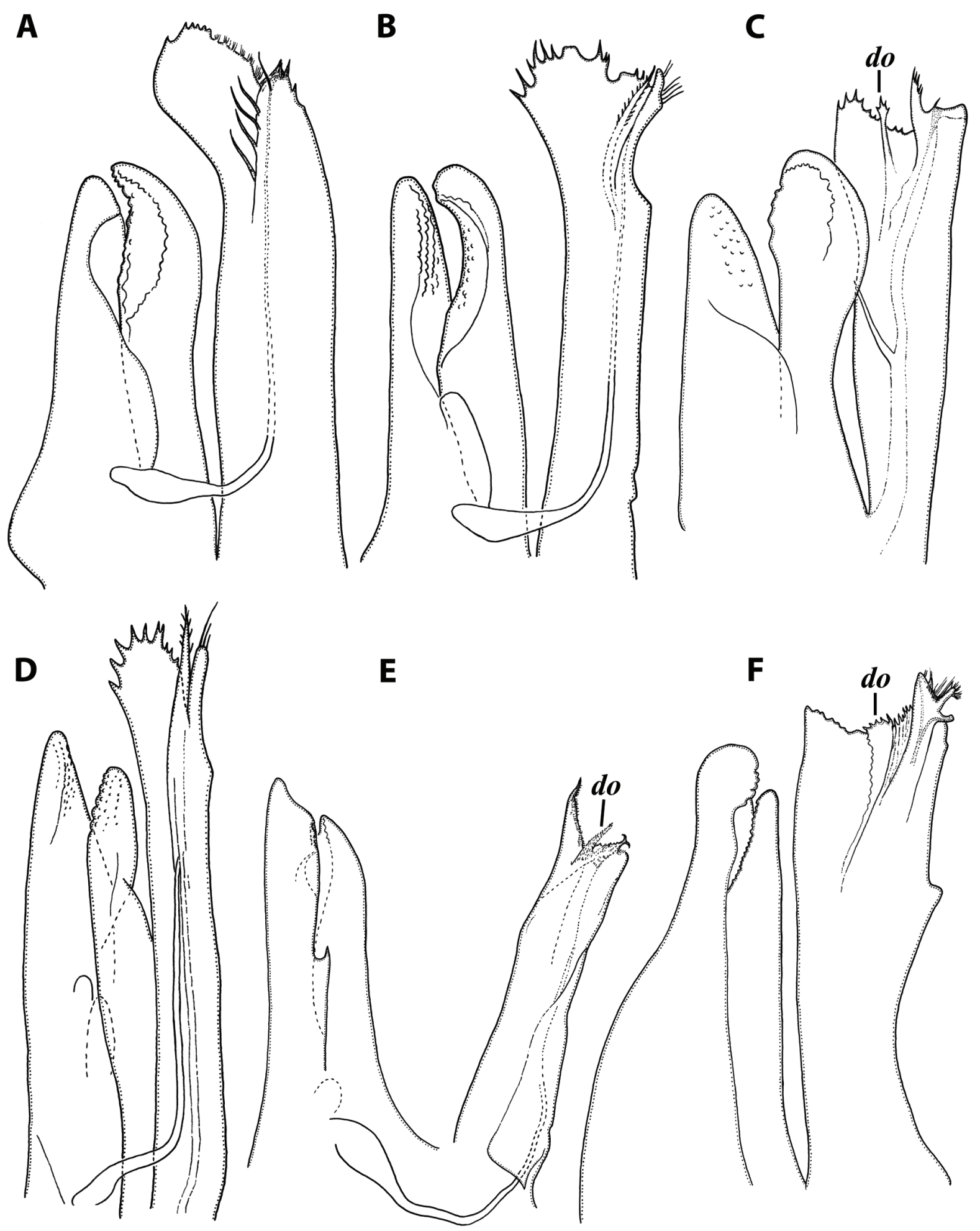

Fig. 10. Left gonopods of species of Stygiiulus stat. nov., mesal views. A. S. ausugi (Manfredi, 1953) comb. nov., topotype ${ }^{\lambda}$ (NHMD). B. S. illyricus (Verhoeff, 1929) comb. nov., redrawn from Verhoeff(1929). C. S. insularis (Strasser, 1938) comb. nov., redrawn from Antić et al. (2018). D. S. maximus (Verhoeff, 1929) comb. nov., redrawn from Verhoeff (1930). E. S. seewaldi (Strasser, 1967) comb. nov., redrawn and modified from Strasser (1967). F. S. tobias (Berlese, 1886) comb. nov., ô from Grotta [Cave] del Subiolo (NHMD). Abbreviations: do = distal outgrowth of velum. Drawn not to scale. 
TARSUS OF MID-BOdY Legs. 1.8-1.9 times as long as tibia and 2.8-4.3 times as long as apical claw. Midbody legs ca 1.25 times as long as $\mathrm{H}$ in males, and equal in length in females.

Female SEXUAL CHARACTERS. Leg-pairs 1 and 2 considerably thicker and shorter than following legs. Vulva (Fig. 11D) nearly symmetric; bursa slightly compressed in the sagittal plane; each valve distally with one vertical row of several setae; a similar row present on each side sclerite; operculum (op) very thick, subconical, i.e., tapering to a distinct blunt apex, exceeding bursa by ca $1 / 5$ of total height of vulva, distally with a dense bunch of setae each side. Receptaculum seminis consisting of two long and narrow, closely adjacent tubes of equal length - a twisted lateral one (lt) leading to a small piriform ampulla (la), and a mostly straight mesal one (mt) ending in a somewhat larger ovoid ampulla (ma).

\section{Distribution}

Known from numerous caves and one epigean locality in the central Venetian Prealps, as well as from several caves in Monti Lessini (extreme south of the Venetian Prealps). Also known from two caves on the southern slopes of Dolomiti (Fig. 13, white squares).

\section{Remarks}

In the past, this taxon was treated as a member of Mesoporoiulus Verhoeff, 1905. Vagalinski et al. (2015) hypothesized it could be a somewhat deviating member of Stygiiulus. Here we fully confirm this assumption and formally transfer tobias to the genus Stygiiulus.

The subspecies S. t. pygmaeus (Manfredi, 1953) comb. nov. has already caught the attention of Strasser (1962). On page 60 of the latter work, the author commented on the significant size difference between pygmaeus (23 $\mathrm{mm}$ of length) and the typical tobias (50-67 mm of length), and also emphasized the apparent confusion of Manfredi (1953b) regarding the gonopods of her newly described subspecies, which she stated to match well (along with most other characters) to the descriptions of tobias given by both Attems (1927) and Verhoeff (1930). In fact, what Attems (1927) recorded and depicted was S. maximus comb. nov. (see Remark under the latter species). The short and straight epiproct in pygmaeus (as originally described), unlike the long and upwards curved process in the typical form, adds further uncertainty about the identity of Manfredi's subspecies. We agree with Strasser's (1962) opinion that pygmaeus most likely represents a separate species. However, its status can only be resolved after examination of type or topotype material.

The gonopods of the two presently examined males from Grotta del Subiolo differ from Verhoeff's (1930) drawings based on material from Grotta Parolini near Vastagna and/or "Bus de la Bela" near San Donato, prov. Belluno, by a blunt and finely serrated, rather than tapering and ciliate, posterior part of velum, and by an apically tri- instead of bipartite solenomere.

In Grotta della Bigonda, this species lives in sympatry with S. ausugi comb. nov.

Key to species of Stygiiulus stat. nov. based on gonopodal and external somatic characters

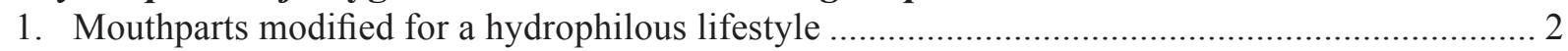

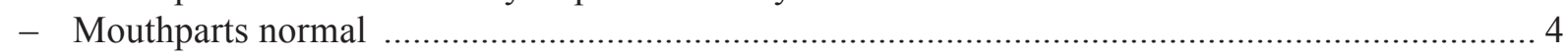

2. Opisthomere completely devoid of a posterior hump and with an anteriorly arched, apically finely fringed velum; both the anterior and the posterior branch of solenomere vestgial

S. ausugi (Manfredi, 1953) comb. nov.

- Opisthomere with a distinct posterior hump and a rather narrow, marginally deeply serrated velum; solenomere with a well-developed, slender posterior branch 3 
3. Promere with the apex turned frontad; velum with serrations on both anterior and posterior margins

S. fimbriatus (Strasser, 1971) comb. et stat. nov.

- Promere distally somewhat bent caudad; velum with serrations only on anterior margin

S. gentianae (Strasser, 1971) comb. et stat. nov.

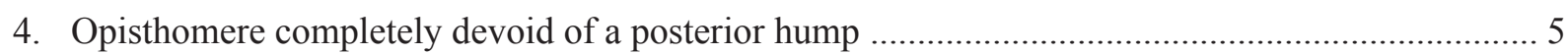

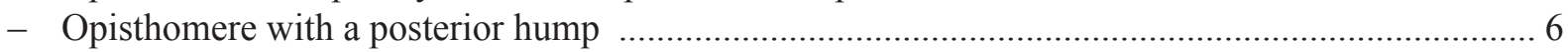

5. Opisthomere with slender, pointed velum, considerably outreaching solenomere; ozopores set at considerable distance behind pro-metazonal suture

S. seewaldi (Strasser, 1967) comb. nov.

- Opisthomere with a rather broad velum being subequal to solenomere; ozopores set just next to, or on, pro-metazonal suture

S. insularis (Strasser, 1938) comb. nov.

6. Mesomere bent strongly frontad; velum clearly outreaching solenomere; anterior branch of solenomere vestigial, completely fused to velum

S. illyricus (Verhoeff, 1929) comb. nov.

- Mesomere more or less straight; velum shorter than, or subequal to, solenomere; anterior branch of solenomere clearly discernible

7. Velum bipartite, the larger anterior part with mostly smooth margins, the posterior one serrated or ciliate; solenomere apically with a rather robust anterior branch and one or two finer posterior branches

S. tobias (Berlese, 1886) comb. nov.

- Velum unipartite, marginally deeply serrated; anterior and posterior branch of solenomere of similar proportions

8. Promere straight, considerably outreaching mesomere; large species (adults 50-70 cm long)

S. maximus (Verhoeff, 1929) comb. nov.

- Promere bent caudad, slightly shorter than mesomere; smaller species (adults 16-35 mm long) ... 9

9. Distal part of mesomere clavate, with a broad and flat apex

S. montellensis (Verhoeff, 1930) comb. nov.

- Distal part of mesomere fronto-caudally compressed, with a narrow, rounded apex

S. rotundatus (Strasser, 1962) comb. et stat. nov.

\section{Additional material of Leptoiulini/Julini and "Typhloiulini" examined}

Vulvae in Julidae can provide valuable taxonomic characters and, in some cases, even carry phylogenetic signals, as suggested by, e.g., Vagalinski \& Lazányi (2018). However, information about vulvae is typically missing from original descriptions including from those referring to julinine (in a broad sense) taxa. Here, in addition to species of Stygiiulus stat. nov., we have observed the vulvae in the type species of Leptoiulus, Typhloiulus s. str., the subgenus Inversotyphlus of Typhloiulus, and a species of Serboiulus in an attempt to find further clues for the systematic position of the study genus, as well as to bring some clarity to the poorly delimited and (partly) overlapping tribes Julini, Leptoiulini and Typhloiulini. Although drawing of any firm conclusions seems to be impossible at this point, certain patterns in the observed vulval structures can be recognized.

Leptoiulus cf. trilineatus (C.L. Koch, 1847)

Fig. 11E

\section{Material examined}

BULGARIA • 1 क; Belasitsa Mtn, Castanea sativa forest; 3-10 May 2010; B. Georgiev and H. Delchev leg.; pitfall trap; IBER. 


\section{Descriptive notes}

Vulva (Fig. 11E). Vulva of nearly equal width in both the sagittal and the transverse planes, mostly symmetric; bursa with a deep and rather broad median cleft; evenly setose throughout, without distinct rows; operculum (op) with markedly concave apical margin, exceeding bursa by ca $1 / 4$ of total height of vulva, distally with several long setae. Receptaculum seminis consisting of a very long and thin, somewhat bent, mesal tube (mt) ending in a medium-sized, piriform ampula (ma), and a somewhat ticker and mostly straight lateral tube (lt) forming a large, strongly elongate ampulla (la) at bottom.

Serboiulus spelaeophilus Gulička, 1967

Fig. $11 \mathrm{~F}$

\section{Material examined}

BULGARIA - 1 q topotype; Belogradchik District, Dolni Lom, Vodni Pech Cave; 25 Feb. 2000; B. Petrov leg.; guano-clay; NMNHS.

\section{Descriptive notes}

Vulva (Fig. 11F). Strongly compressed in the sagittal plane, mostly symmetric; bursa with a shallow and very narrow median cleft; each valve distolaterally with a few setae; operculum (op) with a deeply concave apical margin, just slightly higher than bursa, distally bearing long setae. Receptaculum seminis consisting of two similarly narrow and twisted tubes - a lateral (lt) and a mesal one (mt), each forming an ovoid ampulla at bottom, the lateral one (la) being somewhat larger than the mesal one (ma).

Typhloiulus (Inversotyphlus) lobifer Attems, 1951

Fig. $11 \mathrm{G}$

\section{Material examined}

CROATIA • 1 क; island of Brač, Škrip, Minjera-Bauxite Mine; 11 Sep. 2015; D. Antić leg.; D. Antić ded. 2021; IBER.

\section{Descriptive notes}

Vulva (Fig. 11G). Slender, of nearly equal width in both the sagittal and the transverse planes, slightly asymmetric: lateral valve being somewhat higher than mesal one, as well as more densely setose; bursa with a broad and relatively deep median cleft; several, mostly vertically arranged setae on each valve; operculum (op) with narrowly rounded apical margin, exceeding bursa by ca $2 / 7$ of total height of vulva, distally with a dense submarginal row of setae each side. Receptaculum seminis consisting of a long, thin and twisted mesal tube (mt) ending in a lemon-shaped ampula (ma), and a somewhat ticker, nearly straight, lateral tube (1t), not forming an ampulla at bottom.

Typhloiulus (Typhloiulus) strictus (Latzel, 1882)

Fig. $11 \mathrm{H}$

\section{Material examined}

BULGARIA - 1 ; Lovech District, Kunino, at the entrance of Samuilitsa 2 Cave; 30 Oct. 2020; B. Vagalinski leg.; under large stones with moss; IBER.

\section{Descriptive notes}

Vulva (Fig. 11H). Slender, of nearly equal width in both the sagittal and the transverse planes, mostly symmetric; bursa with a rather broad and deep median cleft; each valve with up to ten, mostly vertically arranged setae; several setae in a vertical row on each side sclerite; operculum (op) with broadly rounded, 
somewhat coarsed, apical margin, exceeding bursa by nearly $1 / 3$ of total height of vulva, distally with a few long setae each side. Receptaculum seminis consisting of a narrow, partly twisted posterior tube (pt) ending in a medium-sized piriform/lemon-shaped ampula (pa), and a much broader, mostly straight anterior tube (at), not forming an ampulla at bottom.

\section{Phylogeny}

A total of 37 taxa (1 outgroup) were included in the analyses. The $28 \mathrm{~S}$ rRNA dataset included $499 \mathrm{bp}$ and 20 gaps. Of these there were 61 variable and 41 parsimony-informative sites. The $16 \mathrm{~S}$ rRNA dataset included 488 bp with 69 gaps, 350 variable and 295 parsimony-informative sites. Maximum likelihood and Bayesian inference analyses showed similar topology, but ML did not obtain strong bootstrap support. The two matrices, analyzed separately, resulted in similar topology but did not resolve deeper nodes (trees not shown). The best resolution was shown by the BI tree, inferred from the concatenated 16S rRNA+28S rRNA dataset (Fig. 12).

Our analyses reproduced the results of previous studies and show agreement with published trees (see Enghoff et al. 2011, 2013; Makarov et al. 2017). The deep nodes did not receive strong support, although some monophyletic clades were strongly supported. These include the tribes Brachyiulini and Pachyiulini, as well as the clade Leucogeorgia + (Pteridoiulus + Heteroiulus) (see Enghoff et al. 2013). Members of the dubious tribe Typhloiulini formed a strongly supported monophyletic clade with the following topology: Rhodopotyphlus mitovi $+(($ Typhloiulus orpheus $+($ T. lobifer + T. gracilis $))+($ T. bureschi + T. georgievi $+($ T. nevoi + (Serboiulus deelemani + Serboiulus lucifugus $)))$ ). The newly represented species Stygiiulus fimbriatus comb. et stat. nov. grouped with Xestoiulus imbecillus (Latzel, 1884), the two forming a sister clade to the monophyletic (julinine/leptoiulinine) group: Ophyiulus pilosus + (Pacifiulus amurensis + (Leptoiulus trilineatus + (Leptoiulus proximus + Julus scandinavius))).

\section{Discussion}

\section{The systematic position of Stygiiulus stat. nov. and the relations between Leptoiulini and Typhloiulini}

Due to their outstanding morphology, species of Stygiiulus stat. nov. have been long recognized as a distinct group within the genus Typhloiulus, and together with Typhloiulus s. str. are arguably its best defined subgenera (Vagalinski et al. 2015). Apart from the slender opisthomere lacking an intermediate lamella and having a large velum and (usually) an apically bifid solenomere, a number of non-gonopodal features, like the penial shape, the upturned or straight rather than downturned epiproct, and the position of the ozopores considerably behind the pro-metazonal suture (in most species) all suggest that Stygiiulus stat. nov. is only distantly related to the nominate subgenus. A possible separate generic status of Stygiiulus stat. nov. has already been considered by Vagalinski et al. (2015) and Antić et al. (2018), although a formal status change was not proposed in any of the two papers.

There are also other subgenera or distinct species/species groups within Typhloiulus that differ significantly from the nominate subgenus, thus questioning the monophyly of the former. Such are the subgenera Spelaeoblaniulus Ceuca, 1956 and Inversotyphlus Strasser, 1962 (as revised by Antić et al. 2018), or the aberrant species T. longipes Strasser, 1973 and T. parvulus Antić \& Dražina, 2018. The molecular-based phylogeny of Typhloiulini or blind Leptoiulini/Julini in Makarov et al. (2017), despite dealing with a limited number of taxa, clearly indicates that Typhloiulus is a poly- or paraphyletic genus in its current composition, as species of $T$. s. str. (not all of the analyzed) appear in one clade together with species of the genus Serboiulus Strasser, 1962, while T. lobifer and T. gracilis [listed as Typhloiulus aff. lobifer] (both belonging to the subgenus Inversotyphlus) form a separate clade. Serboiulus, on the other hand, is morphologically highly distinct, making the paraphyly of Typhloiulus the less plausible possibility than the polyphyly. 


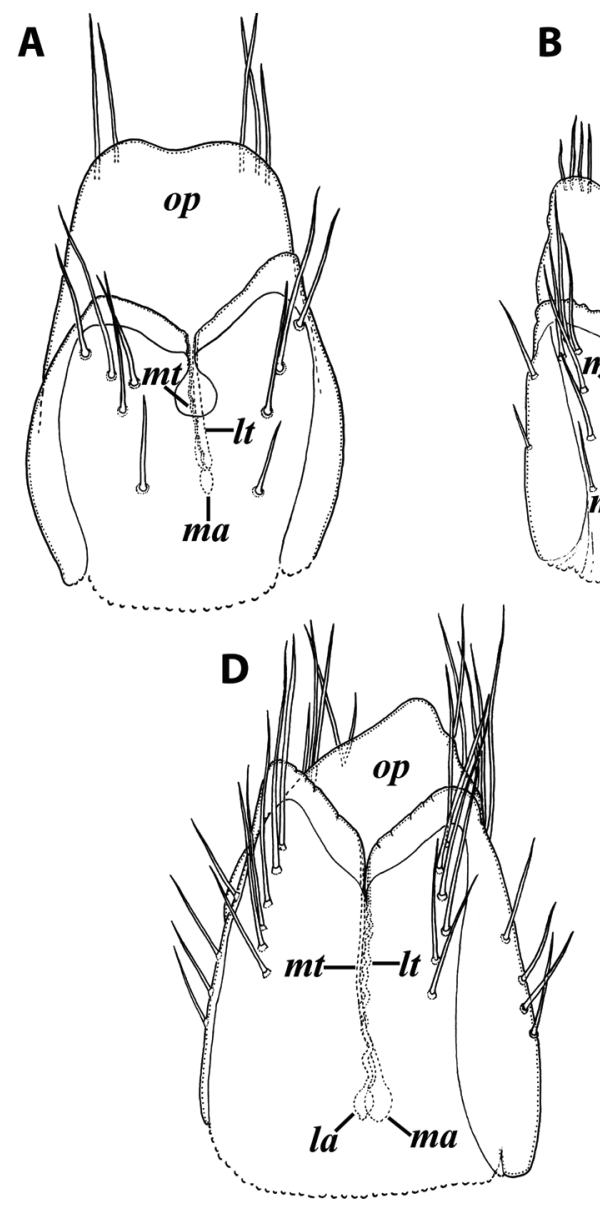

B

C

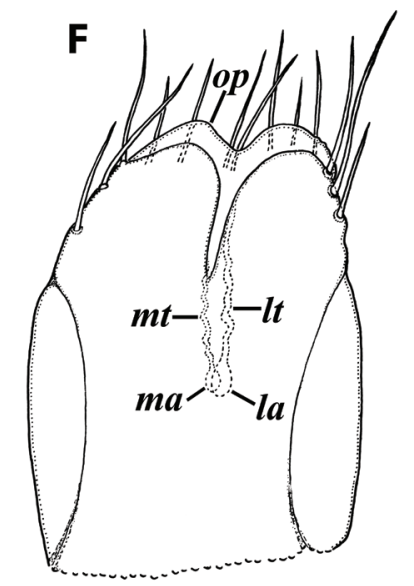

G
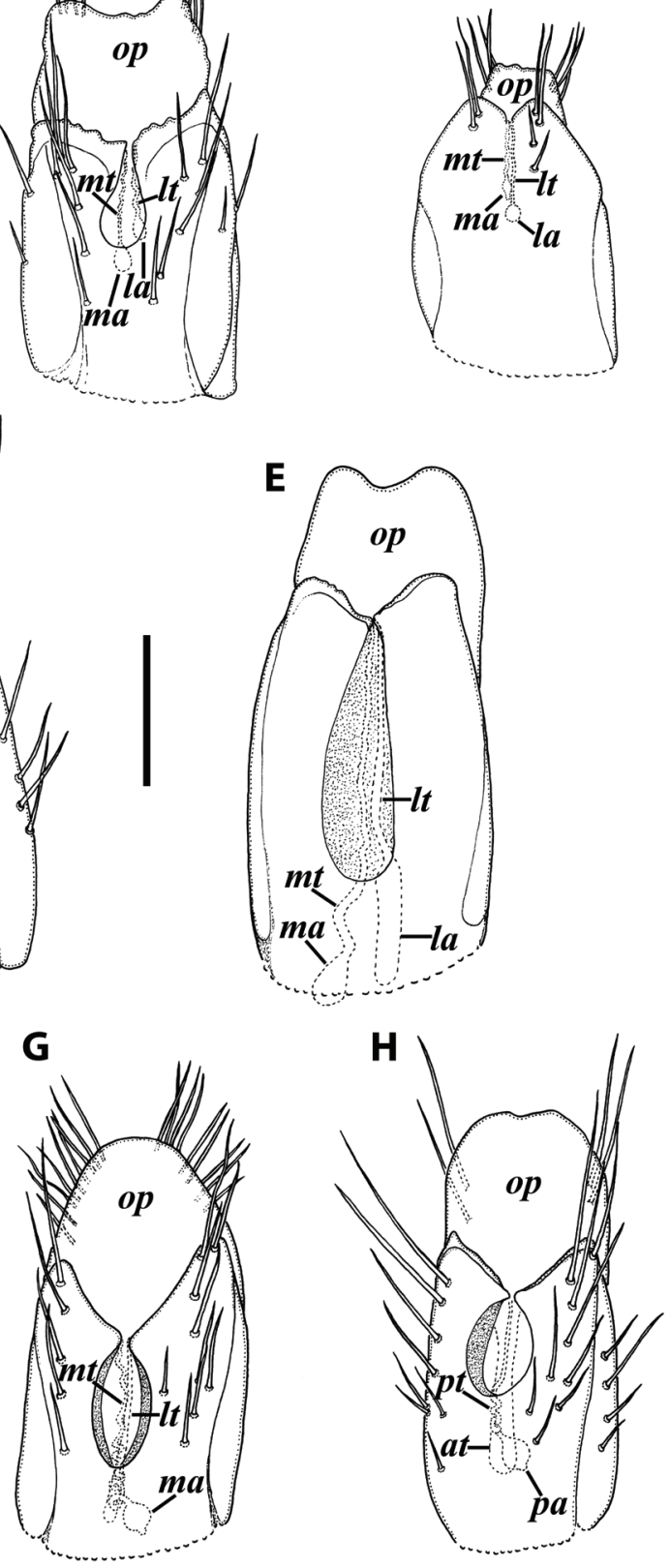

Fig. 11. Left vulvae of species of Stygiiulus stat. nov. (A-D) and representatives of (other) Julini/ Leptoiulini (E) and Typhloiulini/blind Julini/Leptoiulini in caudal, somewhat mesal views. A. S. ausugi (Manfredi, 1953) comb. nov., + from Grotta [Cave] del Calgeron (NHMD). B. S. illyricus (Verhoef, 1929) comb. nov., $q$ from Rabakova Cave (IZB). C. S. insularis (Strasser, 1938) comb. nov., topotype $q$ (CBSS). D. S. tobias (Berlese, 1886) comb. nov., o from Grotta [Cave] del Subiolo (NHMD). E. Leptoiulus cf. trilineatus (C.L. Koch, 1847), q from Belasitsa Mtn, Bulgaria. F. Serboiulus spelaeophilus Gulička, 1967, q from Vodni Pech Cave (NMNHS). G. Typhloiulus (Inversotyphlus) lobifer Attems, 1951, o from Minjera-Bauxite Mine (IBER). H. Typhloiulus (s. str.) strictus (Latzel, 1882), ㅇ from Kunino (IBER). Abbreviations: at $=$ anterior tube; $1 \mathrm{a}=$ lateral ampulla; $1 \mathrm{t}=$ lateral tube; $\mathrm{ma}=$ median ampulla; $\mathrm{mt}=$ median tube; $\mathrm{op}=$ operculum; $\mathrm{pa}=$ posterior ampulla; $\mathrm{pt}=$ posterior tube. Scale $\mathrm{bar}=0.2 \mathrm{~mm}$. 
Interestingly, according to the currently obtained molecular data of Stygiiulus fimbriatus comb. et stat. nov., the species is not only excluded from Typhloiulus, but is also placed outside the 'Typhloiulini' (= Typhloiulus s. str. plus closely related sub/genera), forming a relatively well-supported clade with Xestoiulus imbecillus (Latzel, 1884), the type species of the genus (Fig. 12). Such grouping may initially seem surprising, as Xestoiulus Verhoeff, 1893 is traditionally considered as closely related to Leptoiulus Verhoeff, 1894, both genera being represented by numerous species, of which all are more or less well pigmented and with ommatidia, thus nothing to do with the strongly troglomorphic appearance of Stygiiulus stat. nov. However, careful comparison between the posterior gonopods of $X$. imbecillus and $S$. fimbriatus comb. et stat. nov. reveals a definite structural similarity. Both species are characterized by an apically bifid solenomere, a large velum, and a weakly developed (in X. imbecillus) or absent/ vestigial (in S. fimbriatus comb. et stat. nov.) phylacum. Furthermore, the very characteristic, pointed, distal outgrowth of the velum, although absent in S. fimbriatus comb. et stat. nov., is present (in a more or less similar shape) in Stygiiulus insularis comb. nov. and S. seewaldi comb. nov., as well as (as a less

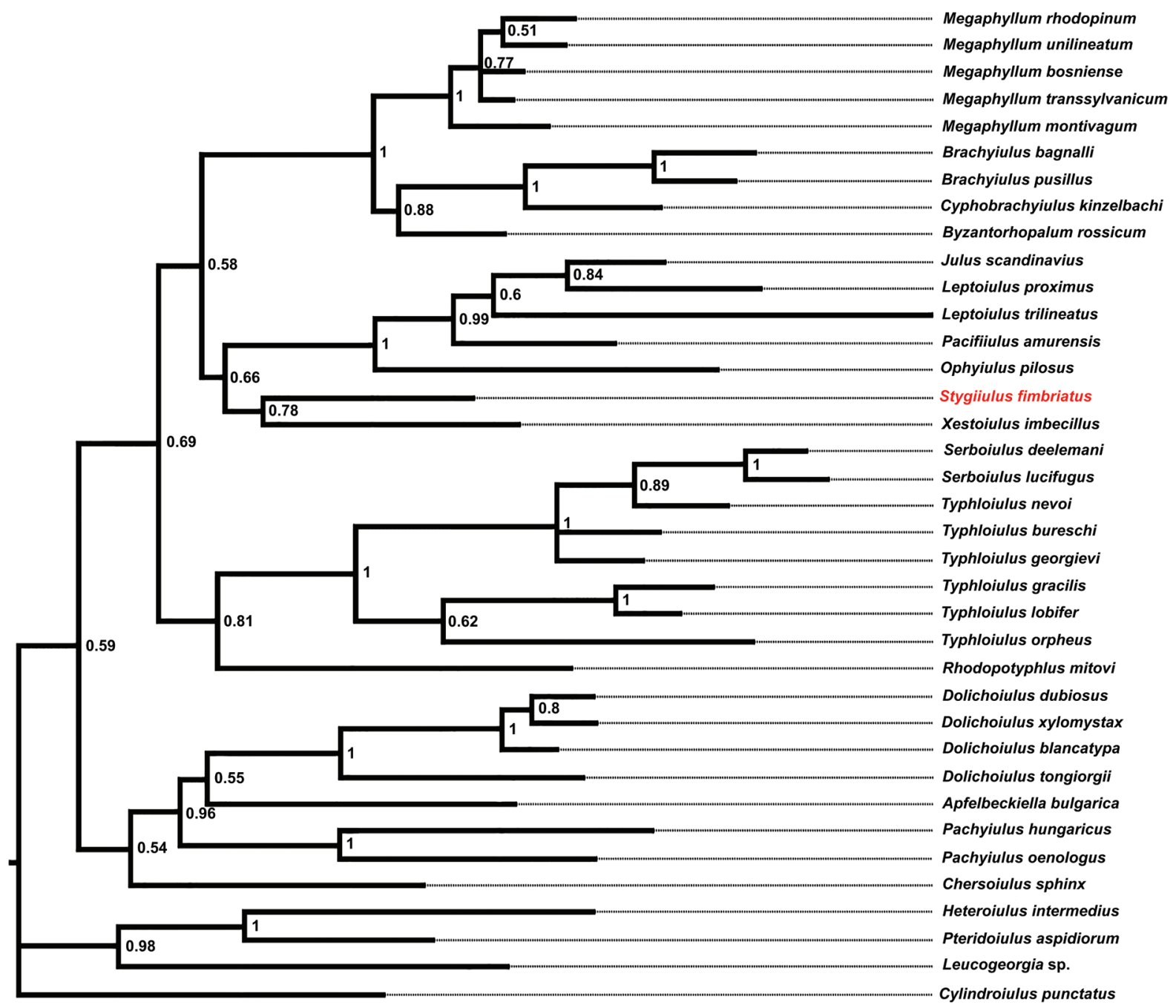

Fig. 12. Bayesian inference tree based on concatenated $16 \mathrm{~S}$ rRNA+28S rRNA dataset from Enghoff et al. (2013) and Makarov et al. (2017). The single species with newly obtained sequences is shown in red. 
conspicuous lamella) in S. tobias comb. nov. There is thus little doubt that Stygiiulus stat. nov. does not belong to 'Typhloiulini', but presents a separate evolutionary lineage that has adapted to subterranean life independently.

While the two newly obtained gene sequences (16S and 28S rRNA) of Stygiiulus fimbriatus comb. et stat. nov. confirm the separate genus status of Stygiiulus stat. nov., they raise more questions regarding the taxonomic compositions of the tribes Leptoiulini/Julini and Typhloiulini and the delimitations between the two/three groups. The only reliable morphological character to distinguish between Leptoiulini and Typhloiulini may be the presence vs absence of phylacum on the opisthomere, respectively (if the posterior hump in Stygiiulus stat. nov. is indeed a vestigial phylacum). Similarities between the two tribes, on the other hand, are numerous and refer to both gonopodal (promere usually with an internal and an external lobe, and with a distally microdentate/squamose caudal face, with the mesomere having a similarly textured frontodistal part; opisthomere with a velum, often with one or several basal spines at flagellum channel, and never with a basolateral lobe) and external somatic (body and appendages more or less slender, occipital setae present, male mandibular stipites not expanded, metazonal setae present, ozopores placed at some distance behind the suture (with very few exceptions), epiproct well-developed), as well as vulval (compare Fig. 11E to Fig. $11 \mathrm{G}$ or $\mathrm{H}$ ) characters. The remarkably similar penial shape in species of Leptoiulus, Ophyiulus Berlese, 1884, Typhloiulus, and Serboiulus (look in Enghoff 1996) add more support to the concept of one large tribe including Leptoiulus plus Typhloiulus and their related genera. The genus Julus Linnaeus, 1758 on the other hand, despite sharing certain similarities with Lepto- and Typhloiulini, is morphologically unique among Julidae with the combination of a very thick gonopodal flagellum, knob-like first pair of male legs, and male coxa 2 with 1-3 processes (Evsyukov et al. 2018).

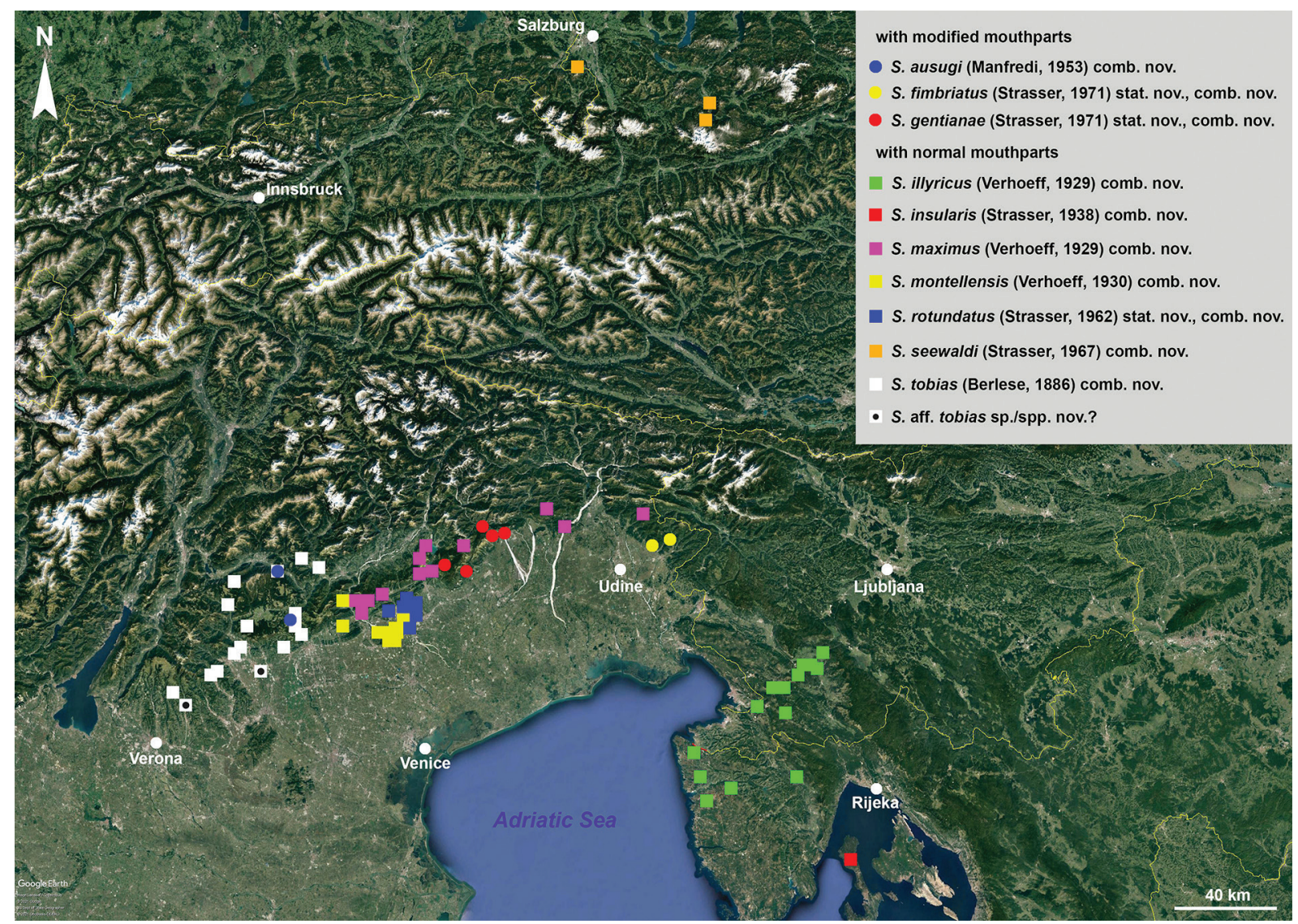

Fig. 13. General distribution of the species of the genus Stygiiulus stat. nov. 
The current molecular evidence, however, points to the existence of two distinct tribes: tribe Julini including Julus and several 'leptoiulinine' genera (both with or without ommatidia), and Typhloiulini encompassing Typhloiulus and Serboiulus. Surprisingly, the two tribes do not even appear to be closely related on most phylogenetic reconstructions: on the single most-parsimonious tree in Enghoff et al. (2013) the only analyzed Typhloiulus species, T. orpheus Vagalinski, Stoev \& Enghoff, 2015 [listed as Typhloiulus sp. nov.], appears far from Julini, in a common clade with members of Calyptophyllini, Catamicrophyllini and Pachyiulini; while in Makarov et al. (2017) Typhloiulus and Serboiulus appear either in a separate basal branch of a large clade including several julid tribes (on the ML-tree) or in one of six branches of an even larger, unresolved clade (on the BI-tree). Our phylogenetic analysis also does not suggest direct common ancestry of Julini and Typhloiulini (Fig. 12). It should be emphasized that Rhodopotyphlus mitovi Vagalinski, 2021 appears as sister group to the typhloiulinine, but not to the julinine/leptoiulinine members included. Considering the supposedly primitive gonopodal conformation of $R$. mitovi (see Vagalinski 2021), its position on the tree indeed implies a division between Julini and Typhloiulini that dates back from the early stages of the evolution of Julidae.

Anyhow, we should bear in mind that the current julid phylogeny is very preliminary, as the number of analyzed taxa is still rather low, and it is based on only two gene fragments: 16S and 28S rRNA. Furthermore, the 28S rRNA fragment gives a rather poor resolution at the genus and tribal levels due to its very high conservatism. It is notable for example that the $28 \mathrm{~S}$ sequences of Julus scandinavius (Latzel, 1884) and Leptoiulus proximus (Nemec, 1896) are completely identical. The inclusion of more gene sequences (e.g., COI, 12S rRNA, or ND2) is likely to lead to significant rearrangements of the clades, and perhaps to a more logical (from a morphological aspect) solution for Julus, Leptoiulus, Typhloiulus and their related genera.

\section{'Hydrophilous' mouthparts in Stygiiulus stat. nov.}

As elaborated above, the genus Stygiiulus stat. nov. includes blind and, mostly, depigmented julids. Of the ten species currently recognized in the genus, six or seven are confined exclusively to caves, while three or four are known both from caves and epigean habitats. Of those troglobionts, three, viz., S. ausugi comb. nov., S. fimbriatus comb. et stat. nov., and $S$. gentianae comb. et stat. nov. are characterized by modified mouthparts, elongated head, shorter body, long legs and large tarsal claws, all connected with a presumed hydrophilous way of life and filtering diet. Modifications in hydrophilous cave julids were recently elaborated by Antić \& Reip (2020). The proportionately shorter body, elongated legs and strong tarsal claws undoubtedly enable these animals to occasionally submerge in cave water bodies, spend time on their surface, or live on vertical wet walls. On the other hand, the elongated head, the reduction of the labral teeth, as well as the hypertrophy of the pectinate lamellae combined with the reduction of the biting parts of mandibles present adaptations for filtering diet in such habitats (see also Enghoff 1985; Antić et al. 2017; Antić \& Reip 2020).

Here, we would like to highlight some intraspecific and/or intrapopulational variability of mouthpart modifications in these three hydrophilous species of Stygiiulus. One of the most obvious mouthpart modification in hydrophilous julids is the complete absence of the three characteristic labral teeth seen in most family members. However, it was already observed by Antić \& Reip (2020) that within two hydrophilous species of Leucogeorgia Verhoeff, 1930, besides specimens with edentate labrum, there were such possessing three minute, reduced, median labral teeth (see Antić \& Reip 2020: 21, fig. 11c; 23, fig. 12e; 94, fig. 55e). The same condition is observed in S. ausugi comb. nov.: Most individuals are characterized by an edentate labrum, but one of the here examined specimens possesses three minute, vestigial, labral teeth. The studied specimens of $S$. fimbriatus comb. et stat. nov. and $S$. gentianae comb. et stat. nov. are even more variable in this respect, having either edentate (Figs 1D, 4D) or normal julid labrum (Figs 1C, 4C), i.e., with three well developed median teeth, these being only insignificantly reduced in some individuals. The two states occur not only intraspecifically but also within the same population. 
Interestingly, specimens with distinct labral teeth have mandibles with less strongly reduced biting parts compared to their counterparts with edentate labrum, while the mandibular pectinate lamellae are equally hypertrophied in both groups. This may suggest that apart from modified body proportions, the first step to hydrophilous/amphibious life and filtering diet in cave julids must be the hypertrophization of the pectinate lamellae, while biting parts of mandibles and the labral teeth are reduced at a later stage. Such an assumption is further supported by the fact that apart from the presence of an extra fifth pectinate lamella in S. ausugi comb. nov., the lamellae are similarly hypertrophied in all three hydrophilous species of Stygiiulus stat. nov., while the mandibular gnathal lobe is strongly reduced and the labral teeth are never well pronounced only in $S$. ausugi comb. nov. However, it is likely that the observed intraspecific variability of mouthparts is at least partly due to lack of stabilizing selection - a common phenomenom concerning organs in the state of reduction, as exemplified by Enghoff (1976) with sexual characters in thelytokous populations of the nemasomatid millipede Nemasoma varicorne C.L. Koch, 1847.

By all means, the modifications in hydrophilous and amphibious julids, which are currently known only from caves in Europe and the Caucasus, are a very interesting phenomenon that will be the subject of future extensive research (Antić et al. in prep.).

\section{Distribution patterns of Stygiiulus stat. nov.}

From the general distribution of Stygiiulus stat. nov. (Fig. 13), it is obvious that the core of the genus' range is in the Venetian Prealps where the largest number of species and localities is registered. This region is inhabited by seven out of ten species of this genus, including three (four) species that can be found also outside caves. Of these, only two species, viz., S. tobias comb. nov. and S. maximus comb. nov., both known from endogean as well as superficious habitats, show a wider distribution, while the rest are narrow local endemics. Stygiulus tobias comb. nov. is the westernmost-occurring species of the genus, ranging from the southern through the central Venetian Prealps, to the southern slopes of the Dolomiti. It partially co-occurs in the central Venetian Prealps with the hydrophilous S. ausugi comb. nov. known only from two caves. S. maximus comb. nov. has the widest distribution range within Stygiiulus stat. nov., stretching from the Piave River in the west, through the Venetian Prealps and the Carnic Alps, all the way to the Julian Alps in the east. Another four species are found within the same region. From west to east these are: S. montellensis comb. nov., S. rotundatus comb. et stat. nov., S. gentianae comb. et stat. nov., and S. fimbriatus comb. et stat. nov. However, it seems that the actual distribution areas of these species, except perhaps that of $S$. gentianae comb. et stat. nov., do not overlap with the distribution of $S$. maximus comb. nov. All four areas are much smaller compared to that of $S$. maximus comb. nov. Both $S$. montellensis comb. nov. and $S$. rotundatus comb. et stat. nov. are limited to a small area on the southern side of the Venetian Prealps' foothill, north of Treviso, with partial overlap. The hydrophilous $S$. gentianae comb. et stat. nov. and S. fimbriatus comb. et stat. nov. are known from several caves in the easternmost part of the Venetian Prealps and two caves in the Italian part of the Julian Alps, respectively.

The remaining three species of the genus Stygiiulus stat. nov. are distributed outside the borders of Italy. S. illyricus comb. nov. occur south of the Julian Alps, in the Istrian peninsula in Croatia and the northwestern Dinarides in Slovenia, where it is known from a large number of subterranean localities. The southernmost representative of the genus is $S$. insularis comb. nov., a species known only from one pit in the northern part of the Croatian island of Cres. Finally, in addition to these nine species distributed on the south side of the main Alpine ridge, one congener, S. seewaldi comb. nov., occur on the other side of the Alps, found in three underground habitats in the Northern Limestone Alps, Germany and Austria. It is interesting to mention that all three "border species" of the genus, viz., S. tobias comb. nov. (westernmost), S. insularis comb. nov. (south-easternmost) and $S$. seewaldi comb. nov. (northernmost) are characterized by some deviations in their gonopod structure compared to the remaining congeners from the "core group". 
It seems that the representatives of the genus Stygiiulus stat. nov. today mostly inhabit underground and epigean habitats up to an altitude of about $1500 \mathrm{~m}$ a.s.l., but the great majority of records come from altitudes below $1000 \mathrm{~m}$ a.s.l., mainly below $700 \mathrm{~m}$ a.s.l. Therefore, it is clear why these species inhabit the slopes in a small region south and north of the main Alpine chain. The distribution of the genus is limited in the south by the Po Valley and the flatlands of Veneto and Friuli. In the west Stygiiulus stat. nov. is replaced with Trogloiulus, while in the southeast it is bordering with the subgenus Inversotyphlus of the genus Typhloiulus. So apparently there is not much room for discoveries of new species of this genus south of the Alps in the future, with the exception of the northern Dinarides in Slovenia, where there is currently a gap in the distribution of Stygiiulus (although it is possible that Typhloiulus carniolensis Strasser, 1940, described on the basis of a single female, is actually a member of Stygiiulus stat. nov.), as well as in the extreme south of the Istrian peninsula in Croatia, were one juvenile of a blind, cave julid similar to Stygiiulus stat. nov. was found (T. Dražina, personal communication). But on the other hand, as for the already questioned $S$. tobias pygmaeus comb. nov., we cannot exclude the presence of more undescribed and undiscovered species in the main distribution area of the genus in Italy. The main gap in the distribution in relation to the core area is in the north, where the genus' range is interrupted by the main chain of the Alps. The question is whether some representatives of Stygiiulus stat. nov. have remained overlooked in the canyons and gorges of the high Alps, or this gap can be explained by the extinction of taxa from this area during colder geological periods, leaving S. seewaldi comb. nov. isolated from all of its extant congeners.

\section{Acknowledgements}

We would like to thank Henrik Enghoff (NHMD), Peter Schwendinger and Lionel Monod (MHNG), Tvrtko Dražina (CBSS), and Pavel Stoev (NMNHS) for making material under their care available to us. Henrik Enghoff is also acknowledged for the useful comments and accurate corrections to an earlier version of the manuscript, and Peter Schwendinger for a suggestion concerning a nomenclatural act. D.A. was partly supported by the Serbian Ministry of Education, Science and Technology (grant no. 451-0368/2022-14/200178).

\section{References}

Antić D.Ž. \& Reip H.S. 2020. The millipede genus Leucogeorgia Verhoeff, 1930 in the Caucasus, with descriptions of eleven new species, erection of a new monotypic genus and notes on the tribe Leucogeorgiini (Diplopoda: Julida: Julidae). European Journal of Taxonomy 713: 1-106. https://doi.org/10.5852/ejt.2020.713

Antić D.Ž., Dudić B.D., Gajić M.R. \& Lučić L.R. 2017. The first hydrophilous cave-dwelling millipede from Serbia - Typhloiulus balcanicus sp. nov. (Diplopoda, Julida, Julidae). Zootaxa 4226 (1): 137-143. https://doi.org/10.11646/zootaxa.4226.1.8

Antić D.Ž., Dražina T., Rađa T., Lučić L.R \& Makarov S.E. 2018. Review of the genus Typhloiulus Latzel, 1884 in the Dinaric region, with a description of four new species and the first description of the male of Typhloiulus insularis Strasser, 1938 (Diplopoda: Julida: Julidae). Zootaxa 4455 (2): 258-294. https://doi.org/10.11646/zootaxa.4455.2.2

Attems C. 1927. Über palaearktische Diplopoden. Archiv für Naturgeschichte 92 (1-2): 1-256.

Attems C. 1949. Die Myriopodenfauna der Ostalpen. Sitzungsberichte, Österreichische Akademie der Wissenschaften, Mathematisch-Naturwissenschaftliche Klasse, Abteilung I 158 (1-2): 79-153.

Boldori L. 1936. Ricerche in caverne italiane (IV serie 1934-1935). Natura XXVII: 106-114.

Boldori L. 1937. Fauna cavernicola. In: Trevisiol G. \& Boldori L. (eds) "Grotte del Vicentino": 10-12. Gruppo Grotte C.A.I., Vicenza. 
Canciani G. 2019. La fauna cavernicola del Foran di Landri. In: A.S. Forum Julii Speleo (ed.) Foran di Landri. Il Landri svelato: ricerche e approfondimenti su una grotta tra storia e folklore: 65-79.

Cognato A.I. \& Vogler A.P. 2001. Exploring data interaction and nucleotide alignment in a multiple gene analysis of Ips (Coleoptera: Scolytinae). Systematic Biology 50 (6): 758-780.

https://doi.org/10.1080/106351501753462803

Conci C. 1951. Contributo alla conoscenza della speleo-fauna della Venezia Tridentina. Memorie della Società Entomologica Italiana, XXX: 5-76.

Enghoff H. 1976. Parthenogenesis and bisexuality in the millipede, Nemasoma varicorne C. L. Koch, 1847 (Diplopoda: Blaniulidae). Morphological, ecological, and biogeographical aspects. Videnskabelige meddelelser fra Dansk Naturhistorisk Forening 139: 21-59.

Enghoff H. 1985. Modified mouthparts in hydrophilous cave millipedes (Diplopoda). In: Ellis W.N., Jeekel C.A.W. \& Pieters F.F.J.M. (eds) Proceedings of the $6^{\text {th }}$ International Congress of Myriapodology. Amsterdam, 12-17 April 1984. Bijdragen tot de Dierkunde 55 (1): 67-77.

Enghoff H. 1996. The penis as a phylogenetic character in the millipede family Julidae. In: Geoffroy J.J., Mauriès J.-P. \& Nguyen Duy-Jacquemin M. (eds) Acta Myriapodologica. Mémoires du Muséum national d'histoire naturelle, N.S. 169: 313-326.

Enghoff H., Petersen G. \& Seberg O. 2011. Phylogenetic relationships in the millipede family Julidae. Cladistics 27 (6): 606-616. https://doi.org/10.1111/j.1096-0031.2011.00360.x

Enghoff H., Petersen G. \& Seberg O. 2013. The aberrant millipede genus Pteridoiulus and its position in a revised molecular phylogeny of the family Julidae (Diplopoda: Julida). Invertebrate Systematics 27: 515-529. http://doi.org/10.1071/IS13016

Evsyukov A., Golovatch S. \& Reip H.S. 2018. The millipede genus Julus Linnaeus, 1758 in the Caucasus (Diplopoda: Julida: Julidae). Zootaxa 4461 (1): 089-117. https://doi.org/10.11646/zootaxa.4461.1.7

Fritsch E. 1998. Die Höhlenfauna des Hirlatzmassivs. In: Buchegger G. \& Greger W. (eds) Die Hirlatzhöhle im Dachstein 52: 136-192. ARGE Hirlatzhöhlenbuch, Hallstadt, Germany.

Golovatch S.I. 2009. Millipedes (Diplopoda) in extreme environments. In: Golovatch S.I., Makarova O.L., Babenko A.B. \& Penev L.D. (eds) Species and Communities in Extreme Environments, Festschrift towards the $75^{\text {th }}$ Anniversary and a Laudatio in Honour of Academician Yuri Ivanovich Chernov: 87-112. Pensoft Publishers \& KMK Scientific Press, Sofia, Moscow.

Kime R.D. \& EnghoffH. 2017. Atlas of European millipedes 2: Order Julida (Class Diplopoda). European Journal of Taxonomy 346: 1-299. https://doi.org/10.5852/ejt.2017.346

Kumar S., Stecher G., Li M., Knyaz C. \& Tamura K. 2018. MEGA X: Molecular evolutionary genetics analysis across computing platforms. Molecular Biology and Evolution 35 (6): 1547-1549.

https://doi.org/10.1093/molbev/msy096

Kutty S.N., Bernasconi M.V., Šifner F. \& Meier R. 2007. Sensitivity analysis, molecular systematics and natural history evolution of Scathophagidae (Diptera: Cyclorrhapha: Calyptratae). Cladistics 23 (1): 64-83. https://doi.org/10.1111/j.1096-0031.2006.00131.x

Lanfear R., Frandsen P.B., Wright A.M., Senfeld T. \& Calcott B. 2017. PartitionFinder 2: new methods for selecting partitioned models of evolution for molecular and morphological phylogenetic analyses. Molecular Biology and Evolution 34 (3): 772-773. https://doi.org/10.1093/molbev/msw260

Latzel R. 1884. Die Myriopoden der österreichisch-ungarischen Monarchie. Zweite Hälfte. Die Symphylen, Pauropoden und Diplopoden. Alfred Hölder, Wien. 
Liu W., Golovatch S., Wesener T. \& Tian, M. 2017. Convergent evolution of unique morphological adaptations to a subterranean environment in cave millipedes (Diplopoda). PLoS ONE 12 (2): 1-20. https://doi.org/10.1371/journal.pone.0170717

Makarov S.E., Bodner M., Reineke D., Vujisić Lj.V., Todosijević M.M., Antić D.Ž., Vagalinski B., Lučić L.R., Mitić B.M., Mitov P., Anđelković B.D., Pavković Lučić S., Vajs V., Tomić V.T. \& Raspotnig G. 2017.Chemicalecology of cave-dwelling millipedes: defensive secretions of the Typhloiulini(Diplopoda, Julida, Julidae). Journal of Chemical Ecology 43 (4):317-326. https://doi.org/10.1007/s10886-017-0832-1

Manfredi P. 1932. Contributo alla conoscenza della fauna cavernicola italiana. Miriapodi. Rivista di Scienze Naturali "Natura" 23: 71-96.

Manfredi P. 1953a. Nuovi miriapodi cavernicoli del Trentino. Studi Trentini di Scienze Naturali 30: $136-139$.

Manfredi P. 1953b. Miriapodi italiani - VIII. contributo. Atti della Società italiana di Scienze naturali, e del Museo civile di Storia naturale 92: 117-122.

Miller M.A., Pfeiffer W. \& Schwartz T. 2011. The CIPRES science gateway: a community resource for phylogenetic analyses. In: Proceedings of the 2011 TeraGrid Conference: Extreme Digital Discovery: 1-8. Association for Computing Machinery, New York. https://doi.org/10.1145/2016741.2016785

Minelli A. 1985. Catalogo dei Diplopodi e dei Chilopodi cavernicoli italiani. Memorie del Museo civico di Storia naturale di Verona, Serie 2 (Sezione scienze della Vita) 4: 1-50.

Muraji M. \& Tachikawa S. 2000. Phylogenetic analysis of water striders (Hemiptera: Gerroidea) based on partial sequences of mitochondrial and nuclear ribosomal RNA genes. Entomological Science 3 (4): $615-626$.

Ozimec R., Bedek J., Gottstein S., Jalžić B., Slapnik R., Štamol V., Bilandžija H., Dražina T., Kletečki E., Komerički A., Lukić M. \& Pavlek M. 2009. Crvena knjiga špiljske faune Hrvatske. [Red book of Croatian cave dwelling fauna]. In: Ozimec R. \& Katušić L. (eds) Ministarstvo kulture. Državni zavod za zaštitu prirode, Zagreb.

Paoletti M.G. 1978. Cenni sulla fauna ipogea delle Prealpi Bellunesi e Colli Subalpini. Le Grotte d'Italia 4 (7): 45-198.

Pretner E. \& Strasser K. 1931. Die Fauna der nordfriauler Höhlen. Mitteilungen über Höhlen- und Karstforschung 1931 (3): 84-90.

RambautA., Drummond A.J., Xie D., Baele G. \& Suchard M.A. 2018. Posterior summarization in Bayesian phylogenetics using Tracer 1.7. Systematic biology 67 (5): 901-904. https://doi.org/10.1093/sysbio/syy032

RonquistF., TeslenkoM., Van DerMarkP.,AyresD.L., DarlingA.,HöhnaS.,LargetB.,Liu L., SuchardM.A.\& Huelsenbeck J.P. 2012. MrBayes 3.2: efficient Bayesian phylogenetic inference and model choice across a large model space. Systematic Biology 61 (3): 539-542. https://doi.org/10.1093/sysbio/sys029

Simon C., FratiF., BeckenbachA., Crespi B., Liu H. \& Flook P. 1994. Evolution, weighting, and phylogenetic utility of mitochondrial gene sequences and a compilation of conserved polymerase chain reaction primers. Annals of the Entomological Society of America 87 (6): 651-701. https://doi.org/10.1093/aesa/87.6.651

Stamatakis A. 2014. RAxML version 8: a tool for phylogenetic analysis and post-analysis of large phylogenies. Bioinformatics 30 (9): 1312-1313. https://doi.org/10.1093/bioinformatics/btu033

Strasser K. 1938. Neue Diplopoden der Insel Cherso. Zoologische Jahrbücher, Abteilung für Systematik, Ökologie und Geographie der Tiere 71 (4-6): 389-407.

Strasser K. 1962. Die Typhloiulini (Diplopoda Symphyognatha). Atti del Museo civico di Storia naturale di Trieste 23 (1): 1-77. 
Strasser K. 1967. Ein Typhloiuline aus den nördlichen Kalkalpen (Diplopoda Symphyognatha). Berichte des naturwissenschaftlich-medizinischen Vereins in Innsbruck 55: 145-153.

Strasser K. 1971a. Über italienische, besonders kavernikole Diplopoden. Memorie del Museo civico di Storia naturale di Verona 19: 1-21.

Strasser K. 1971b. Über Diplopoden Jugoslawiens. Senckenbergiana biologica 53: 313-345.

Vagalinski B. \& Lazányi E. 2018. Revision of the millipede tribe Brachyiulini Verhoeff, 1909 (Diplopoda: Julida: Julidae), with descriptions of new taxa. Zootaxa 4421 (1): 001-142.

https://doi.org/10.11646/zootaxa.4421.1.1

Vagalinski B. 2021. Rhodopotyphlus mitovi gen. et sp. nov., a new endogean millipede from the West Rhodope Mountains, Bulgaria (Diplopoda: Julida: Julidae). Zootaxa 5071: 415-426.

https://doi.org/10.11646/zootaxa.5071.3.7

Vagalinski B., Stoev P. \& Enghoff H. 2015. A review of the millipede genus Typhloiulus Latzel, 1884 (Diplopoda: Julida: Julidae), with a description of three new species from Bulgaria and Greece. Zootaxa 3999 (3): 334-362. https://doi.org/10.11646/zootaxa.3999.3.2

Verhoeff K. 1929. Arthropoden aus südostalpinen Höhlen (I). Gesammelt von Karl Strasser in Triest. Mitteilungen über Höhlen- und Karstforschung 1929: 14-35.

Verhoeff K. 1930. Arthropoden aus südostalpinen Höhlen, gesammelt von Karl Strasser. 5. Aufsatz. Mitteilungen über Höhlen- und Karstforschung 1930 (4): 97-113.

Verhoeff K.W. 1933. Arthropoden aus südostalpinen Höhlen, gesammelt von Karl Strasser. 7. Aufsatz. Mitteilungen über Höhlen- und Karstforschung 1933 (4): 1-21.

Wolf B. 1934-38. Animalium Cavernarus Catalogus. 'sGravenhage, W. Junk, Vol. 3.

Xia X. 2018. DAMBE7: New and improved tools for data analysis in molecular biology and evolution. Molecular Biology and Evolution 35 (6): 1550-1552. https://doi.org/10.1093/molbev/msy073

Manuscript received: 10 September 2021

Manuscript accepted: 30 November 2021

Published on: 28 February 2022

Topic editor: Tony Robillard

Desk editor: Fariza Sissi

Printed versions of all papers are also deposited in the libraries of the institutes that are members of the EJT consortium: Muséum national d'histoire naturelle, Paris, France; Meise Botanic Garden, Belgium; Royal Museum for Central Africa, Tervuren, Belgium; Royal Belgian Institute of Natural Sciences, Brussels, Belgium; Natural History Museum of Denmark, Copenhagen, Denmark; Naturalis Biodiversity Center, Leiden, the Netherlands; Museo Nacional de Ciencias Naturales-CSIC, Madrid, Spain; Real Jardín Botánico de Madrid CSIC, Spain; Zoological Research Museum Alexander Koenig, Bonn, Germany; National Museum, Prague, Czech Republic.

\section{Supplementary file}

Supp. file 1. Species and accession numbers of sequences used in the analyses. https://doi.org/10.5852/ejt.2022.798.1669.6089 